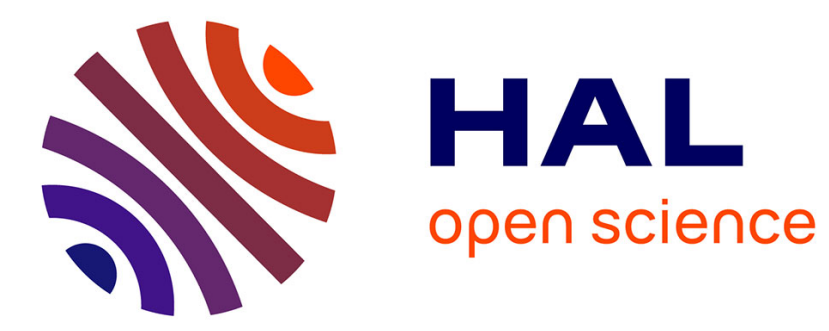

\title{
Origin and evolution of Ngaye River alluvial sediments, Northern Cameroon: Geochemical constraints
}

Paul-Désiré Ndjigui, Anicet Beauvais, Soureiyatou Fadil-Djenabou, Jean-Paul Ambrosi

\section{- To cite this version:}

Paul-Désiré Ndjigui, Anicet Beauvais, Soureiyatou Fadil-Djenabou, Jean-Paul Ambrosi. Origin and evolution of Ngaye River alluvial sediments, Northern Cameroon: Geochemical constraints. Journal of African Earth Sciences, 2014, 100, pp.164 - 178. 10.1016/j.jafrearsci.2014.06.005 . ird-01419945

\section{HAL Id: ird-01419945 \\ https://hal.ird.fr/ird-01419945}

Submitted on 20 Dec 2016

HAL is a multi-disciplinary open access archive for the deposit and dissemination of scientific research documents, whether they are published or not. The documents may come from teaching and research institutions in France or abroad, or from public or private research centers.
L'archive ouverte pluridisciplinaire HAL, est destinée au dépôt et à la diffusion de documents scientifiques de niveau recherche, publiés ou non, émanant des établissements d'enseignement et de recherche français ou étrangers, des laboratoires publics ou privés. 


\section{Accepted Manuscript}

Mineralogical and geochemical features of the coarse saprolite developed on orthogneiss in the SW of Yaoundé, South Cameroon

P.-D. Ndjigui, M.F.B. Badinane, B. Nyeck, H.P.K. Nandjip, P. Bilong

PII:

S1464-343X(12)00225-7

DOI: http://dx.doi.org/10.1016/j.jafrearsci.2012.11.008

Reference: AES 1813

To appear in:

African Earth Sciences

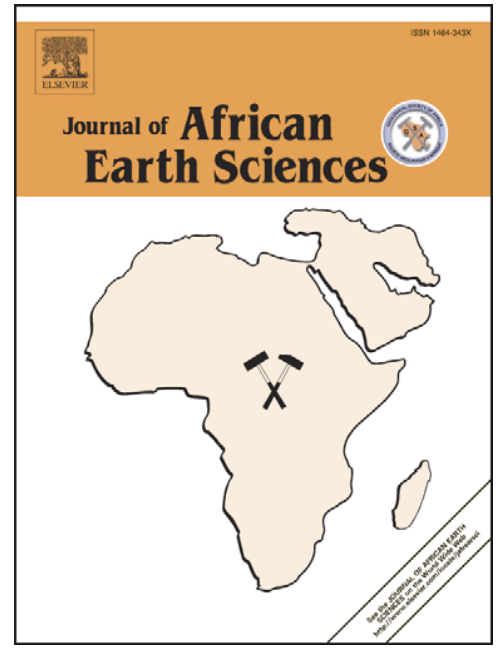

Received Date:

23 November 2011

Revised Date:

27 August 2012

Accepted Date:

13 November 2012

Please cite this article as: Ndjigui, P.-D., Badinane, M.F.B., Nyeck, B., Nandjip, H.P.K., Bilong, P., Mineralogical and geochemical features of the coarse saprolite developed on orthogneiss in the SW of Yaoundé, South Cameroon, African Earth Sciences (2012), doi: http://dx.doi.org/10.1016/j.jafrearsci.2012.11.008

This is a PDF file of an unedited manuscript that has been accepted for publication. As a service to our customers we are providing this early version of the manuscript. The manuscript will undergo copyediting, typesetting, and review of the resulting proof before it is published in its final form. Please note that during the production process errors may be discovered which could affect the content, and all legal disclaimers that apply to the journal pertain. 
1 Mineralogical and geochemical features of the coarse saprolite developed on orthogneiss

2

3

4

5

6

7

8

9

10

11

12

13

14

15

16

17

18

19

20

21

22

23

24

25

26

27

28

29

30

31

32

33 in the SW of Yaoundé, South Cameroon

$$
\text { P.-D. Ndjigui }{ }^{\mathrm{a}, *} \text {, M.F.B. Badinane }{ }^{\mathrm{a}} \text {, B. Nyeck }{ }^{\mathrm{a}} \text {, H.P.K. Nandjip }{ }^{\mathrm{a}} \text {, P. Bilong }{ }^{\mathrm{b}}
$$

${ }^{a}$ Department of Earth Sciences, University of Yaoundé 1, P.O. Box: 812 Yaoundé, Cameroon

${ }^{b}$ Faculty of Science, University of Douala, P.O. Box: 24157 Douala, Cameroon

Corresponding author: Indjigui@yahoo.fr 


\section{Abstract}

A petrological investigation was performed in the coarse saprolite on orthogneiss in Yaoundé (South Cameroon) using combined whole rock geochemical (XRF, ICP-MS) and mineralogical (XRD, SEM) techniques. The orthogneiss has high contents in $\mathrm{SiO}_{2}(61.56$ wt.\%), $\mathrm{Ba}(916 \mathrm{ppm})$ and $\operatorname{REE}(209 \mathrm{ppm})$, moderate content in $\mathrm{Al}_{2} \mathrm{O}_{3}$ (14.34 wt.\%) and negative $\mathrm{Eu}$ anomaly $\left(\mathrm{Eu} / \mathrm{Eu}^{*}=0.68\right)$. The weathering leads to the formation of three main constituents in the coarse saprolite: (i) the loose materials ( $85 \mathrm{vol} . \%)$ are basically clayey silty with relic structure. They are composed of kaolinite, quartz and goethite. The loose materials have high contents in $\mathrm{SiO}_{2}$ (56 to 64.83 wt.\%) and $\mathrm{Al}_{2} \mathrm{O}_{3}$ (21.48 to 23.96 wt.\%), and moderate contents in V (163 to $236 \mathrm{ppm}), \mathrm{Ba}$ (95 to $340 \mathrm{ppm}$ ) and $\mathrm{Zr}$ (160 to $313 \mathrm{ppm}$ ). The REE content is low ( 49 to $169 \mathrm{ppm})$ relative to the parent rock with LREE-enrichment (LREE/HREE $\sim 7$ to 17$)$. Positive Ce anomaly $\left(\mathrm{Ce} / \mathrm{Ce}^{*} \sim 3.35\right)$ is observed in the white veins and slight positive $\mathrm{Eu}$ anomalies $\left(\mathrm{Eu} / \mathrm{Eu}^{*} \sim 1.2\right.$ to 1.4$)$ are noted in all loose samples. The $(\mathrm{La} / \mathrm{Yb})_{\mathrm{N}}$ ratios $(\sim 0.8$ to 1.5$)$ indicate high REE-fractionation. The mass balance calculation reveals the depletion of several elements except $\mathrm{Al}, \mathrm{Ti}, \mathrm{Sc}, \mathrm{Y}, \mathrm{Th}, \mathrm{Sb}$ and Hf; (ii) the iron duricrust $(\sim 10 \mathrm{vol} . \%)$ is located at the bottom and the top of the horizon. The mineral assemblage is dominated by hematite and goethite. The upper iron duricrust has high contents in $\mathrm{Fe}_{2} \mathrm{O}_{3}$ (45.60 wt.\%) and $\mathrm{Cr}(1641 \mathrm{ppm})$, moderate contents in $\mathrm{V}$ (459 ppm) and $\mathrm{Zn}(143$ ppm), and low REE content (47 ppm) with low LREE/HREE ratio (4.28). The upper iron duricrust is more enriched in $\mathrm{Fe}_{2} \mathrm{O}_{3}(53.26$ wt.\%) than the lower one. Vanadium, $\mathrm{Cr}$ and $\mathrm{Zr}$ have high contents relative to other trace elements. The REE content is low (39 ppm) as well as the LREE/HREE ratio (2.94). The iron duricrust has negative $\mathrm{Ce}$ anomalies $\left(\mathrm{Ce} / \mathrm{Ce}^{*} \sim 0.66\right.$ to 0.69$)$ and very low $(\mathrm{La} / \mathrm{Yb})_{\mathrm{N}}$ ratios $(0.1$ to 0.3$)$. Several elements reported in the iron duricrust are highly leached except $\mathrm{Fe}, \mathrm{Cr}, \mathrm{Zn}, \mathrm{Sc}, \mathrm{V}, \mathrm{Pb}, \mathrm{Zr}, \mathrm{Cu}$ and Th; and (iii) the Mn-rich materials $(<5 \mathrm{vol} . \%)$ are made up of birnessite, cryptomelane, and low quantities of quartz, 
59 kaolinite and goethite. The SEM investigation reveals that $\mathrm{Ba}$ and $\mathrm{Pb}$ are linked in $\mathrm{Mn}-$

60 bearing phases and Ce-oxides appear as fine-grained intergrowth between Mn-bearing phases.

61 The Mn-bearing phases are enriched in $\mathrm{MnO}$ (33.86 wt.\%), $\mathrm{BaO}$ (4.30 wt.\%), Co (1716 ppm),

$62 \mathrm{~Pb}(1315 \mathrm{ppm})$ and $\mathrm{Ce}(5202 \mathrm{ppm})$. Positive $\mathrm{Ce}$ and $\mathrm{Eu}$ anomalies are observed $\left(\mathrm{Ce} / \mathrm{Ce}^{*} \sim\right.$

6315.60 and $\mathrm{Eu} / \mathrm{Eu}^{*} \sim 2$ ). The mass balance calculations indicate the strong accumulation of $\mathrm{Mn}$,

$64 \mathrm{Ni}, \mathrm{Co}, \mathrm{Zn}, \mathrm{Sc}, \mathrm{Cu}, \mathrm{Ba}, \mathrm{Pb}, \mathrm{Y}, \mathrm{Ga}, \mathrm{Zr}$ and REE. The Mn-bearing phases might be derived

65 from the accumulation of silicate residues and Mn within the parent rock.

66 The transition from the parent rock to the coarse saprolite is marked by high leaching

67 of several elements.

68

69

Keywords: Yaoundé; Orthogneiss; Coarse saprolite; Mineralogy; Geochemistry; Mass

70 balance

71

72

73

74

75

76

77

78

79

80

81

82

83 


\section{Introduction}

Laterites are the main constituents of weathering mantles in the tropical zone (Mc Farlane, 1976). They are complex materials that derive from the weathering of various rock types (Kamgang Beyala and Ekodeck, 1991; Ndjigui et al., 2008; Etame et al., 2012). Laterites are characterized by large iron duricrust (Beauvais and Colin, 1993; Bitom et al., 2003; Beauvais, 2009). Several works have reported the determination and dating of geochemical fractionation in laterites using U-Th radioactive series (Boulad et al., 1977; Mathieu et al., 1995) or ${ }^{238} \mathrm{U}_{-}{ }^{235} \mathrm{U}_{-}{ }^{230}$ Th nuclides (Chabaux et al., 2003). Chabaux and coworkers (2003) highlighted the chemical mobility in the lateritic profile controlled by the iron-cap dismantling. The REE-geochemistry is a useful complementary tool to elucidate chemical variations in geological systems because of their coherent and predictable behaviour (Leybourne et al., 2000). This behaviour combined with their sensitivity to changes in $\mathrm{pH}$, redox conditions and adsorption/desorption reactions, make the rare-earth elements particularly useful as pedogenetic tracers in external geodynamic studies of the earth.

The geochemical characterization has for long been focused on the distribution of major and five or six trace elements in the whole fraction of each soil horizon along the lateritic profile in the Central African rainforest (Ndjigui et al., 1998; Bitom et al., 2003; Nguetnkam et al., 2006). Many works reported since the 90s included the mineralogy and geochemistry of REE in laterites (Braun et al., 1993, 1998; Ndjigui et al., 2008, 2009; Kamgang Kabeyene Beyala et al., 2009). These works have shown that the redox conditions and the nature of the parent rock control the REE distribution in the weathering mantles. They also display an intense REE accumulation in laterites with strong Ce abundance. The lateritic profile is made up, from the bottom to top, of coarse saprolite, fine saprolite, nodular zone and loose clay horizon (Ndjigui et al., 2008). Each soil horizon is made up of numerous plates and patches with different petrophysical, mineralogical and geochemical characteristics. Previous 
109 works on the petrology of major constituents of horizon are very scarce. The Mn-oxide

110 commonly observed is characterized by a fibrous growth texture. It contains Ba and, in few

111 cases, $\mathrm{K}$. This phase can be assigned to either hollandite $\left(\mathrm{BaMn}_{8} \mathrm{O}_{16}\right)$ or cryptomelane

$112\left(\mathrm{KMn}_{8} \mathrm{O}_{16}\right)$, which are both isostructural 2:2 tunnel manganates and can contain up to 16 wt.\%

113 Ba and 5 wt.\% K, respectively, based on the formula (Loges et al., 2012). The behaviour of

114 cerium is complex in the Mn-oxides; Ce has commonly positive anomaly (Koppi et al., 1996;

115 Ohnuki et al., 2008) due to the stability of $\mathrm{Ce}^{4+}$ at the oxide surface (Ohta and Kawabe, 2001;

116 Takahashi et al., 2000, 2007). The negative Ce anomaly is rarely observed (Loges et al.,

117 2012). This is due to the strong complexation of $\mathrm{Ce}^{4+}$ by siderophores or organic molecules

118 (Davranche et al., 2005, 2008; Loges et al., 2012). At the same time, experimental studies

119 reveal the selective adsorption of REE on kaolinite (Laufer et al., 1984; Coppin et al., 2002).

120 Larger amounts of cerium were adsorbed by natural kaolinite. Cerium may be adsorbed either

121 as a monomeric species or as a polymeric hydroxyl cation (Laufer et al., 1984). In this study,

122 we present detailed mineralogical and geochemical data of three major constituents (loose

123 materials, iron duricrust and Mn-bearing phases) of a coarse saprolite on orthogneiss. The

124 high $\mathrm{Ba}, \mathrm{Pb}$ and $\mathrm{Ce}$ contents in the Mn-bearing phases enabled to determine their stable forms

125 using the microchemistry of the Mn-bearing phases. The last step of this study is the mass

126 balance evaluation of major and trace elements from three main constituents of the coarse

127 saprolite.

128

129 2. Geographical and geological setting

$130 \quad$ The study site is located in the SW of Yaoundé $\left(11^{\circ} 25^{\prime}-11^{\circ} 30^{\prime} \mathrm{E}\right.$ and $3^{\circ} 45^{\prime}-3^{\circ} 50^{\prime} \mathrm{N}$;

131 Fig. 1). The climate is humid tropical with four seasons marked by a mean annual temperature

132 of $24^{\circ} \mathrm{C}$ and an average annual rainfall of $1495 \mathrm{~mm}$ (Suchel, 1987). The vegetation

133 corresponds to a transitional zone between rainforest and savannah (Letouzey, 1985). The 
134 morphology of the Yaoundé area $(\sim 750 \mathrm{~m})$ is dominated by the smooth-rocky hills with large

135 convex slopes relayed by large swampy valleys. The Yaoundé group constitutes a part of the

136 Central African Mobile Zone (CAMZ) and is pan-African in age (Toteu et al., 2006).

137 Micaschists, quartzites and gneiss occur and are intensively folded (Fig. 1B). The Yaoundé

138 group is made up of two series: the Mbalmayo-Bengbis-Ayos and the Yaoundé series

139 (Maurizot et al., 1986). Paragneiss and orthogneiss are predominant in the Yaoundé series

140 (Fig. 1C). The weathering leads to hillside ferrallitic soils and the swampy hydromorphic

141 soils. The whole swamp is overlain by a grey clayey sandy material with depth varying from

1420.5 to $2 \mathrm{~m}$. It is essentially composed of kaolinite and residual quartz, Ti-oxides and zircon 143 grains (Braun et al., 2005).

144

145 3. Sampling and analytical techniques

$146 \quad$ 3.1. Sampling techniques

147 The pit is situated at the hilltop. The weathering profile is $9 \mathrm{~m}$ thick and is made up,

148 from the bottom to top, of a coarse saprolite, a fine saprolite, a lower nodular horizon, an iron

149 duricrust horizon, an upper nodular horizon and a loose clayey horizon (Fig. 2). Eleven

150 weathered samples from the coarse saprolite and two rock samples (fresh and slightly

151 weathered) from the outcrop were collected for mineralogical and chemical analyses in the

152 Geoscience Laboratories (Sudbury, Canada).

153

154 3.2. Analytical techniques

155 Thin sections of rocks were observed with an optical microscope (Euromex).

156 Mineralogical analyses were performed on whole rock powders. Powders were prepared by

157 crushing the samples using an agate mortar. Mineral assemblage of rocks and soils was

158 determined using the Panalytical X'Pert Pro. The controlling software is X'Pert data collector, 
159

160

161

162

163

164

165

166

167

168

169

170

171

172

173

174

175

176

177

178

179

180

181

182

183

version $2.2 \mathrm{~h}$. The analytical conditions are $40 \mathrm{kV}$ and $45 \mathrm{~mA}$. The scan range varies 5 to 85 degrees 2 theta and the step size is 0.01 . The run time is 8 minutes and 30 seconds/scan. The scanning is continuous and the type of radiation is Co. The mineralogical composition is given in Table 1.

Samples were analyzed for major and trace (including lanthanides) elements. They were crushed in an agate mortar and then pulverized in a planetary ball mortar made up of 99.8\% $\mathrm{Al}_{2} \mathrm{O}_{3}$. After crushing, the loss on ignition (LOI) was determined. Firstly, the powders were oven-dried at $105^{\circ} \mathrm{C}$ under nitrogen in order to eliminate water; another sample fraction was heated at $1000^{\circ} \mathrm{C}$ under oxygen so as to remove the volatile components and oxidize iron. After the determination of the LOI, the major element composition was determined by X-Ray Fluorescence (XRF) with a Panalytical Axios Advanced PW 4400 fluorescence spectrometer. The international reference materials (INTL-09-05401, 09-04868 and 09-04869) and internal laboratory standards (ISHT-09-04204, 09-03903 and 09-03904) were used. Comparisons of measured and reference values are available upon request. The precision of analysis is $5 \%$. The detection limits and results of major elements are presented in Table 2. Another fraction of the powder was prepared for the trace elements analysis by Inductively Coupled PlasmaMass Spectrometry (ICP-MS) following the digestion using three acids (see e.g., Burnham and Schweyer, 2004; Ndjigui et al., 2008). The powders were then treated in an acid mixture $\left(\mathrm{HCl}\right.$ and $\left.\mathrm{HClO}_{4}\right)$ at $120^{\circ} \mathrm{C}$ in a closed container for one week, and then rinsed from their containers with dilute $\mathrm{HNO}_{3}$ and dried. The residues were dissolved in an acid mixture $(\mathrm{HCl}$ and $\mathrm{HClO}_{4}$ ) and oven-dried for a second time before they were then dissolved in an acid mixture $\left(\mathrm{HNO}_{3}, \mathrm{HCl}\right.$ and $\left.\mathrm{HF}\right)$ at $100^{\circ} \mathrm{C}$. The dissolved samples were analyzed in a Perkin Elmer Elan 9000 ICP-MS instrument. The instrumental precision of almost all elements was $5 \%(2 \sigma)$ for either all or five of the six compiled solutions where the elements were above the limit of quantification. Where the concentrations approached this limit (e.g., for $\mathrm{Zr}, \mathrm{Ba}, \mathrm{La}$ 
184 and Pr in the trace-element poor basalt standard BIR-1, or Eu in the rhyolite standard RGM-

185 1), the error varies between 5 and $8.5 \%$ (Burnham and Schweyer, 2004).

186 Density measurements were carried out in the Department of Earth Sciences of the

187 University of Yaoundé 1 and the results are presented in Table 3. The bulk density $\left(\rho_{\mathrm{w}}\right)$ was

188 obtained by the paraffin method. The grain densities $\left(\rho_{\mathrm{g}}\right)$ were obtained by the air picnometer

189 method (two replicates). Porosity is calculated using the equation $\Phi=\left[1-\left(\rho_{\mathrm{w}} / \rho_{\mathrm{g}}\right)\right]^{*} 100$.

190 Scanning Electron Microscope (SEM) analysis were carried out at the Geoscience

191 Laboratories using the BSE detector and ED X-ray spectrometer to (i) search for various Mn,

$192 \mathrm{Ba}, \mathrm{Pb}$ and $\mathrm{Ce}$ mineral species due to their high abundances in Mn-bearing phases; and (ii)

193 provide qualitative X-ray data and BSE images of the individual phases. The sample was

194 prepared in three steps: (i) mineral grains and representative pieces of the sample were hand-

195 picked; (ii) several grains were mounted in epoxy plug, polished and carbon coated prior to

196 analysis by SEM; and (iii) several grains were crushed with an agate mortar and pestle, and a

197 smear mount created for XRD analysis. SEM used is a Zeiss EVO 50 and the operating

198 conditions were $20 \mathrm{kV}$ acceleration voltage/ $1 \mathrm{nA}$ beam current.

200 4. Results

201 4.1. Petrology of orthogneiss

202 The orthogneiss is dark, microbedded and has an augen structure. The rock, with

203 heterogranular grano-lepidoblastic texture, is essentially made up of quartz, biotite, green

204 hornblende, garnet, orthoclase, and accessory microcline, opaque minerals and zircon. The

205 XRD spectra reveal the presence of micas (Table 1). The fresh rock is characterized by high

$206 \mathrm{SiO}_{2}$, and moderate $\mathrm{Al}_{2} \mathrm{O}_{3}, \mathrm{Fe}_{2} \mathrm{O}_{3}, \mathrm{MgO}, \mathrm{CaO}, \mathrm{K}_{2} \mathrm{O}$ and $\mathrm{Na}_{2} \mathrm{O}$ contents (Table 2). The slightly

207 weathered sample is characterized by an increase in $\mathrm{SiO}_{2}, \mathrm{Al}_{2} \mathrm{O}_{3}, \mathrm{~K}_{2} \mathrm{O}, \mathrm{TiO}_{2}$ and $\mathrm{P}_{2} \mathrm{O}_{5}$

208 contents (Table 2). The bulk density is 2 ; it is a less porous rock $(27.6 \%$, Table 3$)$. The trace 
209

210

211

212

213

214

215

216

217

218

219

220

221

222

223

224

225

226

227

228

229

230

231

232

233

element contents are variable (Table 4). In the fresh rock, elements whose concentrations are more than 100 ppm include $\mathrm{Cr}, \mathrm{Zn}, \mathrm{V}, \mathrm{Ba}, \mathrm{Zr}, \mathrm{Rb}$ and $\mathrm{Sr}$ (Table 4). The second category, made up of elements with low concentrations (20 to $90 \mathrm{ppm}$ ), include $\mathrm{Ni}, \mathrm{Cu}, \mathrm{Y}, \mathrm{Co}, \mathrm{Li}$ and Ga. The third category is made up of those whose concentrations are below 19 ppm (Table 4). The chondrite-normalized (McDonough and Sun, 1995) multi-element patterns reveal that orthogneiss and their weathered products are depleted in $\mathrm{Co}, \mathrm{Ni}$ and $\mathrm{Cr}$ contrary to several trace elements (Fig. 3). The total REE content is 209 ppm (Table 4). The elements whose concentrations are high (>40 ppm) include La (43.04 ppm), Ce (87.02 ppm) and $\mathrm{Nd}(40.79$ ppm) (Table 5). The orthogneiss is more enriched in LREE (LREE/HREE 10). The chondrite-normalized REE spectra reveal: (i) strong LREE-enrichment; (ii) slight HREEenrichment; and (iii) moderate negative Eu anomaly $\left(\mathrm{Eu} / \mathrm{Eu}^{*}=0.68\right)\left(\right.$ Fig. 4). The $(\mathrm{La} / \mathrm{Yb})_{\mathrm{N}}$ ratios are very high (13.19).

\subsection{Petrology of the coarse saprolite}

\subsubsection{Morphology, mineralogy and distribution of major elements}

The coarse saprolite is $2.50 \mathrm{~m}$ thick (Fig. 2), with a microbedded structure inherited from the parent rock. It is mainly violet red, silty and interspersed with plates of variable colour and texture

The bottom is made up of a brown material and white veins. The brown material ( $\sim 80$ vol.\%) is organized in horizontal, mm-sized, red, grey yellow or white layers. The mineral assemblage is comprised of kaolinite, quartz, goethite, anatase and accessory hematite (Table 1). This material shows high contents in $\mathrm{Al}_{2} \mathrm{O}_{3}$ (22.48 wt.\%) and $\mathrm{TiO}_{2}(1.36$ wt.\%) relative to the orthogneiss (Table 2). The $\mathrm{Fe}_{2} \mathrm{O}_{3}, \mathrm{MnO}, \mathrm{MgO}, \mathrm{CaO}, \mathrm{Na}_{2} \mathrm{O}$ and $\mathrm{K}_{2} \mathrm{O}$ contents decrease strongly from the parent rock to the brown material (Table 2). The white veins occur inside the brown material. They are cm-thick, sandy clayey and oriented parallel to the brown 
234 material. Kaolinite and quartz are the dominated minerals (Table 1). Slight increase of

235 contents in $\mathrm{SiO}_{2}\left(64.83\right.$ wt.\%), $\mathrm{Al}_{2} \mathrm{O}_{3}\left(22.76\right.$ wt.\%) and $\mathrm{TiO}_{2}(1.46$ wt.\%) is observed relative 236 to the orthogneiss (Table 2).

237 The whole fraction of the bottom shows a similar mineralogy and geochemistry like 238 the brown material (Tables 1-2).

239 The upper part is mainly yellowish brown, clayey silty and microbedded. The whole 240 fraction has practically the same mineralogy and geochemistry like the brown material 241 (Tables 1-2). It embeds numerous plates like dark red iron duricrust, black plates, yellowish 242 brown plates and dusky red iron duricrust.

243 The dark red iron duricrust is fusiform ( 2 to $3 \mathrm{~m}$ long and $0.5 \mathrm{~m}$ wide), and includes 244 piled up concentric and cm-layers. It is surrounded by the yellowish brown plate (Fig. 2). The 245 mineral assemblage is made up of hematite, goethite, and few amounts of kaolinite, quartz 246 and anatase (Table 1). The $\mathrm{Fe}_{2} \mathrm{O}_{3}$ content is 53.26 wt.\% and those of $\mathrm{SiO}_{2}$ and $\mathrm{Al}_{2} \mathrm{O}_{3}$ are 26.7 247 and 10.04 wt.\%, respectively.

248 The black phases $(\sim 5 \mathrm{yol} . \%)$ form $\mathrm{cm}$ - to $\mathrm{dm}$-sized lobe-shape. They are porous and 249 very hardened materials. They are made up of birnessite, cryptomelane, with accessory 250 quartz, kaolinite and goethite (Table 1). The X-ray diffraction data of selected grains confirms 251 the presence of the birnessite and cryptomelane groups (Fig. 5). The Mn-bearing phases are 252 very enriched in $\mathrm{Mn}$ (33.86 wt.\%), and depleted in $\mathrm{SiO}_{2}\left(27.97\right.$ wt.\%) and $\mathrm{Al}_{2} \mathrm{O}_{3}(12.16$ 253 wt.\%). The $\mathrm{Fe}_{2} \mathrm{O}_{3}$ content is quite high (10.08 wt.\%) as well as those of other major elements 254 (Table 2).

255 The yellowish brown plates are disseminated with variable shapes and sizes. They are 256 composed of kaolinite, quartz, goethite and few amounts of rutile and anatase (Table 1). The 257 chemical composition is very close to the uppermost part whole fraction one (Table 2). 
The upper boundary of the coarse saprolite is also marked by the presence of dusky

259 red iron duricrust. It is made up of flattened and lobular, interconnected and millimetric

260 plates. The X-ray diffraction data show that hematite and goethite are dominantly associated

261 with few amounts of quartz, kaolinite and anatase (Table 1). The dusky red iron duricrust

262 have high content in $\mathrm{Fe}_{2} \mathrm{O}_{3}\left(45.60\right.$ wt.\%) and moderate contents in $\mathrm{SiO}_{2}(30.79$ wt.\%) and

$263 \quad \mathrm{Al}_{2} \mathrm{O}_{3}(11.90$ wt.\%).

264 The bulk density values range between 0.9 and 2.53 (Table 3). The high values are

265 measured in the lower iron duricrust (2.53) and in the Mn-bearing phases (2.36). The upper

266 iron duricrust is less dense (1.66). The loose materials have low density (0.93-1.42) and

267 moderate porosity $(35-50 \%)$.

268

269

\subsubsection{Distribution of trace elements}

270

271 table of elements:

272

a) - alkaline ( $\mathrm{Li}, \mathrm{Rb}, \mathrm{Cs})$ and alkali-earth $(\mathrm{Be}, \mathrm{Sr}, \mathrm{Ba})$ contents are very low in the

273 loose samples and iron duricrust compared with the parent rock (Table 4). Lithium, Rb, Sr and $\mathrm{Ba}$ contents are high in Mn-bearing phases (Table 4);

b) - scandium, V, Cr, Co, Ni and $\mathrm{Cu}$ contents are low, except $\mathrm{Cr}$ (1641 ppm) and V

276 (459 ppm) in the upper iron duricrust and Co (1716 ppm) in the Mn-bearing phases (Table 4).

277 Other elements also show high contents in Mn-bearing phases (Table 4);

278 c) - yttrium, Nb, Mo, Hf and W show low concentrations except Zr (Table 4). The Zr

279 contents vary from 83 to $316 \mathrm{ppm}$; the lowest content occurs in the upper iron duricrust and

280 the highest one is observed in the white veins. Other trace elements of this series have high

281 contents in the Mn-bearing phases (Table 4); 
d) - other metals (Ga, $\mathrm{Zn}, \mathrm{Cd}, \mathrm{In}, \mathrm{Sn}, \mathrm{Sb}, \mathrm{Tl}$ and $\mathrm{Pb}$ ) show a similar behaviour like

283 those of the previous groups (Table 4). Elements which show high contents include $\mathrm{Pb}(1315$

$284 \mathrm{ppm})$ and $\mathrm{Zn}(242 \mathrm{ppm})$ in the Mn-bearing phases;

285

e) - thorium contents range between 5 and $42 \mathrm{ppm}$. The upper iron duricrust and white

286

287

290

291

292

293

294

295

296

297

298

299

300

301

302

303

304

305

306

\subsubsection{Correlations}

The $\mathrm{SiO}_{2} / \mathrm{Al}_{2} \mathrm{O}_{3}$ and $\mathrm{Fe}_{2} \mathrm{O}_{3} / \mathrm{K}_{2} \mathrm{O}$ ratios show that $\mathrm{Si}$ and $\mathrm{Fe}$ are most abundant than $\mathrm{Al}$ and $\mathrm{K}$ (Table 2). The $\mathrm{Th} / \mathrm{U}$ and $\mathrm{Th} / \mathrm{Co}$ ratios show that orthogneiss and their weathered products are more enriched in Th than U and Co (Table 4). The parent rock-normalized multielement patterns show strong negative Rb anomalies (Fig. 6). The Harker diagrams show that $\mathrm{SiO}_{2}$ has positive correlations with $\mathrm{Al}_{2} \mathrm{O}_{3}, \mathrm{TiO}_{2}, \mathrm{P}_{2} \mathrm{O}_{5}, \mathrm{Y}$ and $\mathrm{U}$ (Fig. 7). However, correlations of $\mathrm{SiO}_{2}$ with $\mathrm{Fe}_{2} \mathrm{O}_{3}, \mathrm{Zr}, \mathrm{Cr}$ and $\mathrm{V}$ are negative. $\mathrm{K}_{2} \mathrm{O}, \mathrm{Rb}$ and $\mathrm{Th}$ have no significant correlations with $\mathrm{SiO}_{2}$ (Fig. 7). The binary diagrams show that $\mathrm{Fe}_{2} \mathrm{O}_{3}$ has a similar trend with ferromagnesian trace elements (Fig. 8). Figure 9 shows (i) strong positive correlations of $\mathrm{Zr}$ with $\mathrm{Hf}, \mathrm{Nb}$ and $\mathrm{U}$; (ii) negative correlations of $\mathrm{Zr}$ with $\mathrm{Y}$ and $\mathrm{Mo}$; and (iii) any correlation between $\mathrm{Zr}$ and $\mathrm{Th}$.

\subsubsection{Behaviour of rare-earth elements}

The total REE content varies between 39 and 5633 ppm (Table 5). The high value is measured in the Mn-phases. The REE content is higher than $100 \mathrm{ppm}$ in two samples and varies from 49 to $96 \mathrm{ppm}$ in several loose samples (Table 5). Both iron duricrust samples have 
307 very low REE content, ranging from 39 to $47 \mathrm{ppm}$. All the weathered samples highlight

308 LREE-enrichment (LREE/HREE $~ 3$ to 86). LREE have strong positive correlations with 309 HREE (Fig. 10).

Overall, the high concentrated REE include La, Ce, Pr, Nd, Sm, Gd and Dy (Table 5).

(Fig. 11A-B). Cerium reveals positive correlation with LREE and REE (Fig. 11C-D). The Ce

\section{3}

314

315

316

317

content influences the behaviour of the bulk LREE and REE. The sum of three lanthanide (La, Ce and $\mathrm{Nd}$ ) contents is moderate to high, ranging from 30 to $5408 \mathrm{ppm}$. Lanthanum, cerium and neodymium are the most abundant REE. The binary diagram $(\mathrm{La}+\mathrm{Ce}+\mathrm{Nd})$ vs. REE shows strong positive correlation of three LREE ( $\mathrm{La}, \mathrm{Ce}$ and $\mathrm{Nd}$ ) with REE (Fig. 11E). Europium shows a moderate positive correlation with $\mathrm{Sr}$ (Fig. 11F).

The parent rock-normalized patterns reveal (Fig. 12A; Table 5): (i) similar behaviour of REE except in the Mn-bearing phases; (ii) slight LREE-depletion; (iii) strong positive Ce and $\mathrm{Eu}$ anomalies in Mn-bearing phases $\left(\mathrm{Ce} / \mathrm{Ce}^{*}=15.57\right.$ and $\left.\mathrm{Eu} / \mathrm{Eu}^{*}=2.01\right)$; (iv) positive $\mathrm{Ce}$ anomaly in white veins $\left(\mathrm{Ce} / \mathrm{Ce}^{*}=3.35\right)$; and $(\mathrm{v})$ moderate negative $\mathrm{Ce}\left(\mathrm{Ce} / \mathrm{Ce}^{*} \sim 0.66\right.$ to 0.86$)$ and weak positive $\mathrm{Eu}$ anomalies $\left(\mathrm{Eu} / \mathrm{Eu}^{*} \sim 1.18\right.$ to 1.40$)$ in the loose materials and in the iron duricrust. The chondrite-normalized (McDonough and Sun, 1995) patterns reveal the similar trend like the parent rock-normalized spectra (Fig. $12 \mathrm{~B})$. The $(\mathrm{La} / \mathrm{Yb})_{\mathrm{N}}$ ratios range between 0.12 and 1.63 (Table 5).

\subsubsection{SEM analysis of Mn-phases}

The SEM analysis is initiated to understand the distribution of several elements with high concentrations like $\mathrm{Mn}, \mathrm{Pb}, \mathrm{Ba}$ and $\mathrm{Ce}$ inside the Mn-rich materials. Under SEM, the Mn-rich material has concentric structure (Figs. 13-14). Barium is detected in all Mn-bearing phases that were analyzed from numerous pieces of the sample. Kaolinite is also detected in 
332 the Mn-bearing phases with $\mathrm{Al} / \mathrm{Si}$ ratio $~ 1$ (Fig. 13). In addition, the atomic ratio of $\mathrm{Ba} / \mathrm{K}$ is

333 always $>1$ suggesting that the cryptomelane component could be termed 'hollandite'. The

334 'typical" birnessite type composition using the SEM is not identified; the birnessite structure 335 in this case also contains significant $\mathrm{Ba}$, where the ratio of $\mathrm{Ba} / \mathrm{K}$ also exceeds 1 . Cyclical 336 growth patterns are evident in the sample (Fig. 13). The SEM investigation also reveals a 337 much less abundant $\mathrm{Pb}$ bearing Mn-phase, perhaps the corandite member of the cryptomelane 338 group. Ce-oxide phase is also relatively common in this sample. In some cases, it forms a rim 339 around the sample or is contained between the apparent growth rings (Fig. 14). There appears

340 to be a fine grained intergrowth between the Mn-bearing phase and an aluminosilicate mineral 341 with a stoichiometry that is consistent with kaolinite (Figs. 14-15).

\subsection{Mass balance calculation}

344 The mass balance calculation is a method that enables one to confirm the mobility of 345 chemical elements during weathering. This is done by the estimation of losses or gains of 346 matter expressed either in per cent or $\mathrm{kg} / \mathrm{m}^{3}$ of the weathered parent material. The method 347 currently used takes into account the concentrations, the bulk density and the volume 348 (Brimhall and Dietrich, 1987; Colin and Ambrosi, 1993; Mungall and Martin, 1994; 349 Beauvais, 1999; Cornu et al, 1999; Moroni et al., 2001; Tollari et al., 2008). This method 350 enables one to estimate the quantity of each element which is depleted or accumulated (Colin

351 et al., 1993). This approach can be summarized by the following equations:

352 The first equation is that of Millot and Bonifas (1955), improved by Brimhall and 353 Dietrich (1987):

$$
\mathrm{K}_{j m}=\left\{\left(\left(\mathrm{C}_{j w} \times \rho_{w}\right) /\left(\mathrm{C}_{j p} \times \rho_{p}\right)\right)-1\right\} \times 100
$$


where $\mathrm{K}_{j m}$ is the enrichment or depletion factor, $\mathrm{C}_{\mathrm{jw}}$ is the concentration of the element

$356 j$ in the weathered material $w, \mathrm{C}_{j p}$ is the concentration of the element $j$ in the fresh rock $p, \rho_{j w}$

357 is the bulk density of the weathered material $w$, and $\rho_{j p}$ is the bulk density of the parent rock $p$.

358 The total mass $m_{j w}$ of each chemical element is obtained through the application of the 359 following equation by Colin et al. (1993):

360

$\mathrm{mg} / \mathrm{kg}, \rho_{p}$ is the bulk density of the parent rock in $10^{3} \mathrm{~kg} / \mathrm{m}^{3}, \mathrm{~V}_{p}$ is the volume of the parent

363 rock in $\mathrm{m}^{3}\left(\mathrm{Vp}=1 \mathrm{~m}^{3}\right), \mathrm{K}_{j m}$ is the enrichment or depletion factor of the element $j$ in the 364 weathered material $w$.

Equation \#2 gives the mass $m$ (in $\mathrm{kg}$ or $\mathrm{g}$ ) of each element that is transferred per unit volume of the parent rock during the weathering.

The application of the previous equations leads to results presented in Tables $6,7,8,9$,

10 and 11 . The mass balance calculations reveal a clear disparity in the behaviour of elements

369 in the coarse saprolite.

370

\subsubsection{Relative element mobility}

The relative mobility of major elements enables one to classify them into four categories (Table 7): (i) the strongly depleted elements (depletion rate $>90 \%$ ) such as $\mathrm{Mn}$,

374 alkaline and alkali-earths, and P; (ii) the second category is made up of moderately leached 375 elements (leaching rate $\sim 50 \%$ ) such as $\mathrm{Fe}$ and $\mathrm{Si}$; (iii) the third category is made up of 376 weakly leached elements such as $\mathrm{Al}$ and $\mathrm{Ti}$; and (iv) the fourth category is that of moderately

377 leached elements to strongly accumulated elements in several materials notably Fe in the iron 378 duricrust, $\mathrm{Mn}$ in the Mn-bearing phases and $\mathrm{Ti}$ in some loose samples from the top of the 379 coarse saprolite. 
Trace elements display a high mobility compared to the major elements. The notable

381 accumulation is found within Mn-bearing phases with more than ten elements (Table 8).

382 Three or four trace elements are accumulated in most samples from the upper part of the 383 coarse saprolite. In all, trace elements are leached from this horizon (Table 8).

384 The behaviour of REE is very close to that of trace elements. Lanthanides are strongly 385 depleted (rate $>60 \%$ ) except in the Mn-bearing phases (Table 9).

\subsubsection{Mass balance calculation}

388 The weathering of $1 \mathrm{~m}^{3}$ of orthogneiss into coarse saprolite indicates: (i) strong depletion of an important quantity of $\mathrm{Si}(400$ to $726 \mathrm{~kg}$ ); (ii) low accumulation of $\mathrm{Al}$ in the whole fraction from the upper part $(17.85 \mathrm{~kg})$, in the yellowish brown plates $(24.45$ and 14.05

$391 \mathrm{~kg}$ ); (iii) more pronounced depletion of Fe than Al (Table 9). However, Fe is strongly 392 accumulated in the Mn-bearing phases $(95.98 \mathrm{~kg})$, in the iron duricrust from the bottom (1205 $393 \mathrm{~kg}$ ) and from the top (615.05 kg); (iv) high $\mathrm{Mn}$ accumulation in the Mn-bearing phases

394 (796.48 kg) and leaching of Mn in several samples (Table 9); (v) strong depletion of alkaline 395 and alkali-earth elements (Table 9); (vi) moderate Ti and P depletion; (vii) accumulation of Ti 396 in the upper whole fraction $(1.31 \mathrm{~kg})$, in the lower iron duricrust $(1.44 \mathrm{~kg})$, and in loose 397 materials (Table 9); (viii) relative accumulation of $\mathrm{Pb}, \mathrm{Zr}, \mathrm{Th}, \mathrm{Hf}, \mathrm{Sc}, \mathrm{V}$ and $\mathrm{U}$ in several 398 loose samples (Table 10); (ix) relative accumulation of $\mathrm{Zn}, \mathrm{Sc}, \mathrm{V}, \mathrm{Pb}, \mathrm{Th}, \mathrm{U}, \mathrm{Cr}, \mathrm{Zn}, \mathrm{Cu}$ and $399 \mathrm{Zr}$ in the iron duricrust (Table 10); (xi) accumulation of $\mathrm{Ba}, \mathrm{Co}, \mathrm{Pb}, \mathrm{Ni}, \mathrm{Zn}, \mathrm{Sc}, \mathrm{Cu}, \mathrm{V}, \mathrm{Y}, \mathrm{Ga}$, $400 \mathrm{U}, \mathrm{Zr}, \mathrm{Sb}, \mathrm{Hf}, \mathrm{Cd}, \mathrm{Mo}$ and Tl in the Mn-bearing phases (Table 10); (xii) high REE-enrichment 401 in the Mn-bearing phases particularly Ce (Table 11); and (xiii) high REE-depletion in almost 402 all the weathered samples (Table 11). 
405

406

407

408

409

410

411

412

413

414

415

416

417

418

419

420

421

422

423

424

\section{Discussion}

\subsection{Petrology of orthogneiss}

The mineralogy and geochemistry indicate that orthogneiss are derived from plutonic rocks. These plutonic rocks might be heterogeneous and characterized by a very variable chemistry. The increase of porosity from the fresh rock to the slightly weathered one might be the result of the dissolution of primary minerals. In the slightly weathered rock, the slight increase in $\mathrm{K}_{2} \mathrm{O}$ is due to adsorption and the increase in $\mathrm{Al}_{2} \mathrm{O}_{3}$ is due to the silicate dissolution. The total moderate REE content might be due to the low proportion of primary REE-bearing minerals (allanite, monazite, xenotime and apatite) in the gneissic formations of South Cameroon (Braun et al., 1998). The negative Eu anomaly could be due to the partial dissolution of feldspars (Gromet and Silver, 1983; Panahi et al., 2000).

\subsection{Petrology of the coarse saprolite}

\subsubsection{Morphology, mineralogy and distribution of major elements}

The presence of several phases in the coarse saprolite reveals that the high degree of weathering favours the thinning out of the large microbedded layers observed at the bottom. The mineralogical composition reveals two mineral phases: (i) the first one is composed of kaolinite, goethite, quartz, gibbsite, hematite and anatase. Kaolinite, goethite and gibbsite are characteristic of the well-drained environments in the rainforest region (Nguetnkam et al., 2006). The high quartz proportion is related to acid nature of the parent rock, as well as its slow dissolution during weathering. Goethite might be related to the high porosity that seemingly facilitates the stagnation of water in cavities. It has already been strongly documented that goethite is the main Fe-hydroxide that crystallizes in the saprolite zone (Tardy, 1993; Delvigne, 1998). Hematite results from the dehydration of goethite (Tardy, 1993); and (ii) the second mineral phase is mainly manganiferous. It is characteristic of Mn- 
430 rich materials which might derive directly from the accumulation of silicate residues and $\mathrm{Mn}$

431 within the parent rock (Bourgauth and Rabenhorst, 2011). The presence of the concentric 432 structures could result from successive centripetal reorganizations (Beauvais and Nahon, 433 1985).

434 The high $\mathrm{SiO}_{2}$ contents might be related to the low degree of quartz dissolution 435 (predominant mineral in these samples) in the rainforest zone (Nandjip, 2010). The sharp drop 436 in the concentrations of alkaline and alkali-earth elements might be linked to a rapid 437 dissolution of carrier minerals. The increase in aluminium contents might be correlated with 438 an intense weathering and formation of kaolinite. High Mn contents have been noted in the 439 lower horizons of Ni-laterites in New Caledonia (Golightly, 1979; Llorca and Monchoux, 440 1991; Traoré, 2005). The positive correlations of $\mathrm{SiO}_{2}$ with $\mathrm{Al}_{2} \mathrm{O}_{3}, \mathrm{TiO}_{2}, \mathrm{P}_{2} \mathrm{O}_{5}, \mathrm{Y}$ and $\mathrm{U}$ 441 confirm that $\mathrm{Si}$ and $\mathrm{Al}$ are the main constituents of silicate residues. At the same time, Ti, $\mathrm{P}$, $442 \mathrm{Y}$ and $\mathrm{U}$ might be associated with the relic minerals. The negative correlation between $\mathrm{SiO}_{2}$ 443 and $\mathrm{Fe}_{2} \mathrm{O}_{3}$ is due to the weathering of ferromagnesian primary minerals (e.g., biotite, green 444 hornblende) and the formation of goethite and hematite.

\subsubsection{Trace elements}

The behaviour of trace elements is also dependent on the nature of weathered phases.

448 The Mn-phases are characterized by their high contents in more than ten trace elements

449 including $\mathrm{Ni}, \mathrm{Co}, \mathrm{Zn}, \mathrm{Cu}, \mathrm{Ba}, \mathrm{Pb}, \mathrm{Y}, \mathrm{Li}, \mathrm{Cd}, \mathrm{Mo}$ and $\mathrm{Tl}$. These highly concentrated elements 450 might have been adsorbed by precipitation in the interlayer spaces of Mn-oxides (Brindley 451 and Brown, 1980; Mishra et al., 2007). The high Cd contents are related to its fixation by 452 adsorption on kaolinite (Vasconcelos et al., 2008). The highest $\mathrm{Cr}$ contents observed in the 453 upper iron duricrust result from relative $\mathrm{Cr}$ accumulation as mineral species that were not 454 identified by X-ray diffraction or from their incorporation in the lattice of goethite (Singh et 
455 al., 2002). The negative $\mathrm{Nb}$ anomalies confirm the high mobilization of $\mathrm{Nb}$ during

456 weathering. The correlation between $\mathrm{Fe}_{2} \mathrm{O}_{3}$ and ferromagnesian trace elements reveals that

457 ferromagnesian trace elements could be fixed by adsorption on goethite. Both positive 458 correlations ( $\mathrm{Zr}$ vs. $\mathrm{Hf}, \mathrm{Nb}$ vs. $\mathrm{U}$ ) show that $\mathrm{Zr}, \mathrm{Hf}, \mathrm{Nb}$ and $\mathrm{U}$ could be hosted by the same 459 minerals such as zircon. The flat signature between $\mathrm{Zr}$ and $\mathrm{Th}$ shows that zircon is not 460 probably the main Th-bearer.

\subsubsection{Rare-earth elements}

463 The low REE content in the loose materials and iron duricrust are characteristic of the 464 weathered materials developed on acidic parent rock (Kamgang Kabeyene Beyala et al., 465 2009). This might be due to the rapid dissolution of REE-bearers (Braun et al., 1998). 466 Meanwhile, the LREE-enrichment is inherited from the parent rock; this could be also due to 467 the formation of secondary LREE-bearers such as rhabdophane $\left(\mathrm{LREEPO}_{4} \cdot \mathrm{nH}_{2} \mathrm{O}\right)(\mathrm{Braun}$ et 468 al., 1998). Braun and co-workers (1998) have reported that xenotime is the major HREE469 bearer in gneiss; the low HREE content in the coarse saprolite is controlled by the dissolution 470 of xenotime. The REE content in the Mn-bearing phases is very high (5632 ppm) as compared 471 to those of the parent rock (209 ppm) and other weathered samples ( $\mathrm{REE}$ is 39-169 ppm).

472 The formation and distribution of secondary minerals have an effect on the REE distribution 473 (Harlavan et al., 2009). The positive correlation of HREE with LREE confirms the coherent 474 behaviour of REE in the coarse saprolite. The positive correlation of the sum of three 475 lanthanide ( $\mathrm{La}, \mathrm{Ce}$ and $\mathrm{Nd}$ ) contents with the total REE content confirms the prevalence of $476 \mathrm{La}, \mathrm{Ce}$ and $\mathrm{Nd}$ inside REE. The high Ce content (5202 ppm) in the Mn-bearing phases is due 477 to the stronger sorption of $\mathrm{Ce}^{4+}$ or to the probable Ce precipitation as cerianite $\left(\mathrm{CeO}_{2}\right)$ onto 478 Mn-hydroxides (Huang and Wang, 2004; Laveuf and Cornu, 2010; this study). The strong 479 positive Ce anomaly results from the lower mobility of $\mathrm{Ce}^{4+}$ than $\mathrm{REE}^{3+}$ (Yoshida et al., 2004; 
480 Tanaka et al., 2010). This positive Ce anomaly is commonly observed in manganese oxides

481 (Koppi et al., 1996; Ohnuki et al., 2008; Feng, 2010). Also, positive Ce anomaly in the

482 kaolinitic white veins indicates that $\mathrm{Ce}$ might have been retained by adsorption into the 483 intracellular crystals of kaolinite (Coppin et al., 2002; Vasconcelos et al., 2008). Laufer and 484 co-workers (1984) have shown that Ce (IV) forms several hydroxyl complexes such as $485[\mathrm{Ce}(\mathrm{OH})]^{3+}$ and $\left[\mathrm{Ce}(\mathrm{OH})_{2}\right]^{2+}$. The number of hydroxyls which are coordinated to Ce depends 486 on the $\mathrm{pH}$ and the age of the solution (Laufer et al., 1984). The negative Ce anomalies in 487 several samples show that cerium exists in trivalent form as other $\mathrm{REE}^{3+}$ (Marsh, 1990; 488 Leybourne et al., 2000; Ndjigui et al., 2009). The positive Eu anomalies might be due to either 489 the dissolution of feldspars or to other supergene mechanism. Europium might partially 490 substitute $\mathrm{Ca}^{2+}$ and $\mathrm{Sr}^{2+}$ in feldspars (Gromet and Silver, 1983; Panahi et al., 2000). The 491 proportion of relic primary minerals (e.g.: feldspars, zircon) and secondary minerals (e.g.: 492 kaolinite, goethite) control the major and trace element distribution (Dequencey et al., 2006).

494

496

500 (Ndjigui et al., 2008; Lambiv Dzemua et al., 2011). The Al accumulation might be due to the 501 fact that aluminium is included within kaolinite. Those of $\mathrm{Fe}$ in the iron duricrust suggest an 502 autochthonous origin by leaching of the uppermost ferruginous horizon (Dequencey et al., 503 2002). The mobility of trace elements is intimately related to the weathering. The high REE504 depletion might be linked to the dissolution of REE-bearers (Boulangé and Colin, 1994). 
505

506

507

508

509

510

511

512

513

514

515

516

517

518

519

520

521

522

523

524

525

526

527

528

529

\section{Conclusion}

This study enables us to understand the mobilization and redistribution of major and trace elements inside the variegated coarse saprolite represented by three main constituents:

1) - loose materials have simple mineral assemblage (quartz, kaolinite and goethite) and slight positive $\mathrm{Eu}$ anomalies. However, strong positive $\mathrm{Ce}$ anomaly is observed in the kaolinitic white veins;

2) - iron duricrsut is hematitic and goethitic with negative $\mathrm{Ce}$ and positive $\mathrm{Eu}$ anomalies;

3) - Mn-bearing phases are dominated by birnessite and cryptomelane groups. They show: (i) higher Mn and trace element contents than other weathered samples; (ii) high REE abundance; and (iii) strong positive $\mathrm{Ce}$ and Eu anomalies. Ce-oxides appear as fine grained in the Mn-bearing phases.

Weathering helps in accumulation of $\mathrm{Al}$ and $\mathrm{Ti}$ in the loose samples and numerous elements (Fe, Mn, Cr, Ni, Co, Zn, Sc, Cu, V, Ba, Pb, Y, Ga, Zr, Th and Tl) in the iron duricrust and Mn-bearing phases. This study shows that the nature and the proportion of weathered phases have a prominent influence on the horizon mineralogical and geochemical budget.

\section{Acknowledgements}

This work was partially supported by the Geoscience Laboratories (Sudbury, Canada) from the stages of sample preparation to laboratory analysis; we wish to thank Clement Merilla, John Hechler and Dave Crabtree for the SEM observations. The authors gratefully acknowledge the editor and two anonymous reviewers for their detailed comments that have considerably improved the manuscript. 
530

531

532

533

534

535

536

537

538

539

540

541

542

543

544

545

546

547

548

549

550

551 Braun, J.-J., Ndam Ngoupayou J.R., Viers, J., Dupre, B., Bedimo Bedimo J.-P., Boeglin, J.-

552 L., Robain, H., Nyeck, B., Freydier, R., Sigha Nkamdjou, L., Rouiller, J., Muller, J.-P., 2005.

553 Present weathering rates in a humid tropical watershed: Nsimi, South Cameroon. Geochimica

554 et Cosmochimica Acta 69, 357-387. 
555 Braun, J.-J., Pagel, M., Herbillon, A., Rosin, C., 1993. Mobilization and redistribution of

556 REEs and Th in syenitic lateritic profile: - a mass-balance study. Geochimica et

557 Cosmochimica Acta 57, 4419-4434.

558 Braun, J.-J., Viers, J., Dupre, B.,Polve, M., Ndam, J., Muller, J.-P., 1998. Solid/liquid REE

559 fractionation in the lateritic system of Goyoum, East Cameroon: the implication for the

560 present dynamics of the soil covers of the humid tropical regions. Geochimica et

561 Cosmochimica Acta 62, 273-299.

562 Brimhall, G.H., Dietrich, W.E., 1987. Constitutive mass-balance relations between chemical

563 composition, volume, density, porosity and strain in metasomatic hydrochemical systems:

564 results on weathering and pedogenesis. Geochimica et Cosmochimica Acta 51, 567-587.

565 Brindley, G.W., Brown, G., 1980. Crystal structures of clay minerals and their x-ray

566 identification. Mineralogical Society, London, p. 495.

567 Burnham, O.M., Schweyer, J., 2004. Trace element analysis of geological samples by

568 inductively Coupled Plasma Mass Spectrometry at the Geoscience Laboratories: revised

569 capabilities due to improvements to instrumentation. Summary of Field Work and Other

570 Activities 2004, Ontario Geological Survey, Open file report 6145, 54, 1-20.

571 Chabaux, F., Dequincey, O., Lévèque, J.-J., Leprun, J.-C., Clauer, N., Riotte, J., Paquet, H.,

572 2003. Tracing and dating recent chemical transfers in weathering profiles by trace-element

573 geochemistry and ${ }^{238} \mathrm{U}_{-}^{234} \mathrm{U}_{-}^{230} \mathrm{Th}$ disequilibria: the example of the Kaya lateritic

574 toposequence (Burkina-Faso). C.R. Geoscience 335, 1219-1231.

575 Colin, F., Ambrosi, J.-P., 1993. Gold mass transfer during lateritic weathering under

576 equatorial rainforest conditions. Chemical Geology 107, 285-288.

577 Colin, F., Veillard, P., Ambrosi, J.-P., 1993. Quantitative approach to physical and chemical 578 gold mobility in equatorial rainforest lateritic environment. Earth Planetary Science Letters $579114,269-285$. 
580 Coppin, F., Berger, G., Bauer, A., Castet, S., Loubet, M., 2002. Sorption of lanthanides on 581 smectite and kaolinite. Chemical Geology 182, 57-68.

582 Cornu, S., Lucas, Y., Lebon, E., Ambrosi, J.-P., Luizão, F., Rouiller, J., Bonnay, M., Neal, C., 583 1999. Evidence of titanium mobility in soil profiles. Manaus, Central Amazonia. Geoderma $58491,281-295$.

585 Davranche, M., Pourret, O., Gruau, G., Dia, A., Jin, D., Gaertner, D., 2008. Competitive 586 binding of REE to humic acid and manganese oxide: impact of reaction kinetics on 587 development of cerium anomaly and REE adsorption. Chemical Geology 247, 154-170.

588 Davranche, M., Pourret, O., Gruau, G., Dia, A., Le Coz-Bouhnik, M., 2005. Adsorption of 589 REE(III)-humate complexes onto $\mathrm{MnO}_{2}$, experimental evidence for cerium anomaly and 590 lanthanide tetrad effect suppression. Geochimica et Cosmochimica Acta 69, 4825-4835.

591 Delvigne, J.E., 1998. Atlas of micromorphology of mineral alteration and weathering. The 592 Canadian Mineralogist, special publication 3, p. 494.

593 Dequencey, O., Chabaux, F., Clauer, N., Sigmarsson, O., Liewig, N., Leprun, J.-C., 2002.

594 Chemical mobilizations in laterites: Evidence from trace elements and ${ }^{238} \mathrm{U}_{-}{ }^{234} \mathrm{U}_{-}{ }^{230} \mathrm{Th}$ 595 disequilibria. Geochimica et Cosmochimica Acta 66, 1997-1210.

596 Dequencey, O., Chabaux, F., Leprun, J.-C., Paquet, H., Clauer, N., Larque, P., 2006.

597 Lanthanide and trace element mobilization in a lateritic toposequence: inferences from the 598 Kaya laterite in Burkina Faso. European Journal of Soil Science 57, 816-830.

599 Etame, J., Suh, C.E.,Gerard, M., Bilong, P., 2012. Phillipsite formation in nephelinitic rocks 600 in response to hydrothermal alteration at Mount Etinde, Cameroon. Chemie der Erde601 Geochemistry 72, 31-37.

602 Feng, J.L., 2008. Behaviour of rare earth elements and yttrium in ferromanganese concretions, 603 gibbsite spots, and surrounding terra rossa over dolomite during chemical weathering. 604 Chemical Geology 271, 112-132. 
605 Galán, E., Fernández-Caliani, J.C., Miras, A., Aparicio, P., Márquez, M.G., 2007. Residence

606 and fractionation of rare earth elements during kaolinization of alkaline peraluminous granites

607 in NW Spain. Clays Minerals 42 (3), 341-352.

608 Golightly, J.-P., 1979. Geology of Soroako nickeliferous laterite deposits. AIME International 609 laterite Symposium, pp. 38-55.

610 Gromet, P.L., Silver, L.T., 1983. Rare earth element distributions among minerals in a 611 granodiorite and their petrogenetic implications. Geochimica et Cosmochimica Acta 47 (5), 612 925-939.

613 Harvalan, Y., Erel, Y., Blum, J.D., 2009. Coupled release of REE and $\mathrm{Pb}$ to the soil labile 614 pool with time by weathering of accessory phases, wind river mountains, WY. Geochimica et 615 Cosmochimica Acta 73, 320-336.

616 Huang, C., Wang, C., 2004. Geochemical characteristics and behaviors of rare earth elements 617 in process of vertisol development. Journal of Rare Earths 22 (4), 552-557.

618 Kamgang Beyala, V., Ekodeck, G.E., 1991. Altération et bilans géochimiques des biotites des 619 gneiss de Nkolbisson (NW de Yaoundé, Cameroun). Géodynamique 6 (2), 191-199.

620 Kamgang Kabeyene Beyala, V., Onana V.L., Ndome Effoudou Priso, E., Parisot, J.-C., 621 Ekodeck, G.E., 2009. Behaviour of REE and mass balance calculations in a lateritic profile 622 over chlorite schists in South Cameroon. Chemie der Erde-Geochemistry 69, 61-73.

623 Koppi, A.J., Edis, R., Field, D.J., Geering, H.R., Klessa, D.A., Cockayne, D.J.H., 1996. Rare 624 earth element trends and cerium-uranium-manganese associations in weathered rock from 625 Koongarra, Northern Territory, Australia. Geochimica et Cosmochimica Acta 60, 1695-1707.

626 Lambiv Dzemua G., Mees F., Stoops G., Van Ranst E., 2011. Micromorphology, mineralogy 627 and geochemistry of lateritic weathering over serpentinite in south-east Cameroon. Journal of 628 African Earth Sciences 60, 38-48. 
629 Laufer, F., Yariv, S., Steinberg, M., 1984. The adsorption of quadrivalent cerium by kaolinite.

630 Clay Minerals 19, 137-149.

631 Laveuf, C., Cornu, S., 2010. A review on the potentiality of rare earth elements to trace 632 pedogenetic processes. Geoderma 154, 1-12.

633 Letouzey, R., 1985. Notice explicative de la carte phytogéographique du Cameroun à

634 l'échelle de 1/500 000. Institut de la Carte Internationale de la Végétation, Toulouse, p. 240.

635 Leybourne, M.I., Goodfellow, W.D., Bowle, D.R., Hall, G.M., 2000. Rapid development of 636 negative $\mathrm{Ce}$ anomalies in surface waters and contrasting REE patterns in ground waters 637 associated with $\mathrm{Zn}-\mathrm{Pb}$ massive sulphide deposits. Applied Geochemistry 15, 695-793.

638 Llorca, S., Monchoux, P., 1991. Supergene cobalt minerals from New Caledonia. Canadian 639 Mineralogist 29, 149-161.

640 Loges, A., Wagner, T., Barth, M., Bau, M., Göb, S., Mark1, G., 2012. Negative Ce anomalies 641 in Mn oxides: the role of $\mathrm{Ce}^{4+}$ mobility during water-mineral interaction. Geochimica et 642 Cosmochimica Acta 86, 296-317.

643 Marsh, J.S., 1990. REE fractionation and Ce anomalies in weathered Karoo dolerite. 644 Chemical Geology 90, 189-194.

645 Mathieu, D., Bernat, M., Nahon, D., 1995. Short-lived U and Th isotope distribution in a 646 tropical laterite derived from granite (Pitinga River Basin, Amazonia, Brazil): application to 647 assessment of weathering rate. Earth Planetary Science Letters 136, 703-714.

648 Maurizot, P., Abessolo, A., Feybesse, A., Johan, V., Lecomte, P., 1986. Etude et prospection 649 minière du Sud-Ouest Cameroun. Synthèse des travaux de 1978 à 1985. 85-CMR 066 BRGM. 650 McDonough, W.F., Sun, S.S., 1995. The composition of the Earth. Chemical Geology 120, $651223-253$.

652 McFarlane, M.J., 1976. Laterite and landscape. Academic Press, London, p. 151. 
653 Millot, G., Bonifas, M., 1955. Transformations iso-volumiques dans les phénomènes de

654 latéritisation et de bauxitisation. Bulletin du Service de la Carte Géologique d'Alsace-

655 Lorraine 8, 8-10.

656 Mishra, P.P., Mohapatra, B.K., Singh, P.P., 2007. Contrasting REE signatures on manganese 657 ores of iron ore group in North Orissa, India. Journal of Rare Earths 25, 749-758.

658 Moroni, M., Girardi, V.A.V., Ferrario, A., 2001. The Serra Pelada Au-PGE deposit, Serra dos

659 Cerajás (Pará State, Brazil): geological and geochemical indications for a composite 660 mineralising process. Mineralium Deposita 36, 768-785.

661 Mungall, J.E., Martin, R.F., 1994. Severe leaching of trachyte glass without devitrification,

662 Terceira, Azores. Geochimica et Cosmochimica Acta 58, 75-83.

663 Nandjip K.P.H., 2010. Contribution à l'étude pétrologique d'une isaltérite développée sur 664 orthogneiss au SW de Yaoundé : recherche des indices de cérium dans les matériaux 665 ferruginisés. Master, Univ. de Yaoundé I, p. 70.

666 Ndjigui, P.-D., Bilong, P., Bitom, D., 2009. Negative cerium anomalies in the saprolite zone 667 of serpentinite lateritic profiles in the Lomié ultramafic complex, South-East Cameroon. 668 Journal of African Earth Sciences 53, 59-69.

669 Ndjigui, P.-D., Bilong, P., Bitom, D., Dia, A., 2008. Mobilization and redistribution of major 670 and trace elements in two weathering profiles developed on serpentinite in the Lomié 671 ultramafic complex, South-East Cameroon. Journal of African Earth Sciences 50, 305-328.

672 Ndjigui, P.-D., Bilong, P., Nyeck, B., Eno Belinga, S.-M., Vicat, J.-P., Gérard, M., 1998. Les 673 produits d'altération du gneiss à biotite et amphibole dans la plaine côtière de Douala. 674 Annales Fac. Sci., série Sci. Nat. et Vie, vol. 34, 191-216.

675 Nguetnkam, J.-P., Yongue-Fouateu, R., Bitom, D., Bilong, P., Volkoff, B., 2006. Etude 676 pétrologique d'une formation latéritique sur granite en milieu tropical forestier sud- 
677 camerounais (Afrique centrale). Mise en évidence de son caractère polyphasé. Etude et 678 Gestion des Sols 13, 89-102.

679 Ohnuki, T., Ozaki, T., Kozai, N., Nankawa, T., Sakamoto, F., Sakai, T., Suzuki, Y., Francis, 680 A.J., 2008. Concurrent transformation of $\mathrm{Ce}(\mathrm{III})$ and formation of biogenic manganese 681 oxides. Chemical Geology 253, 23-29.

682 Ohta, A., Kawabe, I., 2001. REE(III) adsorption onto $\mathrm{Mn}$ dioxide $\left(\delta-\mathrm{MnO}_{2}\right)$ and Fe 683 oxyhydroxide: $\mathrm{Ce}(\mathrm{III})$ oxidation by $\left(\delta-\mathrm{MnO}_{2}\right)$. Geochimica et Cosmochimica Acta 65 (5), $684 \quad 695-703$.

685 Owona, S., Mvondo Ondoa, J., Essono, J., Tjomb, B., Enama Mengong, M., 2003. 686 Géomorphologie et cartographie de deux faciès paradérivés et un orthodérivé de la région de 687 Yaoundé. Sci. Technol. Dev., Vol. 10 (1), 81-91.

688 Panahi, A., Young, G.M., Rainbird, R.H., 2000. Behavior of major and trace elements 689 (including REE) during Paleoproterozoic pedogenesis and diagenetic alteration of an 690 Archaean granite near Ville Marie, Québec, Canada. Geochimica et Cosmochimica Acta 64 691 (13), 2199-2220.

692 Singh, B., Sherman, D.M., Gilkes, R.J., Wells, M.A., Mosselmans, J.F.W., 2002. 693 Incorporation of $\mathrm{Cr}, \mathrm{Mn}$ and $\mathrm{Ni}$ into goethite $(\alpha-\mathrm{FeOOH})$ : mechanism from extended X-ray 694 absorption fine structure spectroscopy. Clay Minerals 37, 636-649.

695 Suchel, J.-B., 1987. Les climats du Cameroun. Thesis, Université de Bordeaux III, p. 1186.

696 Takahashi, Y., Manceau, A., Geoffroy, N., Marcus, M.A., Usui, A., 2007. Chemical and 697 structural control of the partitioning of $\mathrm{Co}, \mathrm{Ce}$, and $\mathrm{Pb}$ in marine ferromanganese oxides. 698 Geochimica et Cosmochimica Acta 71, 984-1008.

699 Takahashi, Y., Shimizu, H., Usui, H., Kagi, H., Nomura, M., 2000. Direct observation of 700 tetravalent cerium in ferromanganese nodules and crusts by x-ray-absorption near-edge 701 structure (XANES). Geochimica et Cosmochimica Acta 17, 2929-2935. 
702 Tanaka, K., Tani, Y., Takahashi, Y., Tanimizu, M., Suzuki, Y., Kozai, N., Ohnuki, T., 2010.

703 A specific Ce oxidation process during sorption of rare earth elements on biogenic Mn oxide 704 produced by Acremonium sp. Strain KR21-2. Geochemica et Cosmochemica Acta 74, 54637055477.

706 Tardy, Y., 1993. Pétrologie des latérites et des sols tropicaux. Masson, Paris, p. 459.

707 Tollari, N., Barnes S.-J., Cox, R.A., Nabil, H., 2008. Trace element concentrations in apatites

708 from the Sept-Îles intrusive suite, Canada - Implications for the genesis of nelsonites.

709 Chemical Geology 252, 180-190.

710 Toteu, S., Penaye, J., Deloule, E., Van Schmus, W.R., Tchameni, R., 2006. Diachronous

711 evolution of volcano-sedimentary basins north of the Congo craton: insights from U-Pb ion

712 microphobe dating zircon from Poli, Lom and Yaoundé groups (Cameroon). Journal of

713 African Earth Sciences 44, 428-442.

714 Traoré, D., 2005. Serpentinisation hydrothermale et altération latéritique des roches

715 ultrabasiques en milieu tropical: évolution géochimique et minéralogique de la minéralisation

716 en platine de la rivière des Pirogues (Nouvelle-Calédonie). Thesis, Université de la Nouvelle

717 Calédonie, p. 191.

718 Tripathi, J.K., Rajamani, V., 2007. Geochemistry and origin of ferruginous nodules in

719 weathered granodioritic gneisses, Mysore Plateau, Southern India. Geochimica et

720 Cosmochimica Acta 71 (7), 1674-1688.

721 Vasconcelos, I.F., Haack, E.A., Maurice, P.A., Bunker, B.A., 2008. EXAFS analysis of 722 cadmium (II) adsorption to kaolinite. Chemical Geology 249, 237-249.

723 Yoshida, T., Ozaki, T., Ohnuki, T., Francis, A.J., 2004. Adsorption of rare earth elements by $724 \gamma-\mathrm{Al}_{2} \mathrm{O}_{3}$ and Pseudomonas fluorescens cells in the presence of desferrioxamine B: implication 725 of siderophores for the Ce anomaly. Chemical Geology 212, 239-246. 
728 Fig. 1. Location and geological map of Yaoundé. A. Location of Yaoundé; B. Geological map

729 of the SW Cameroon (modified after Maurizot et al., 1986); C. Geological map of the $730 \quad$ Yaoundé (modified after Owona et al. 2003).

731

732 Fig. 2. Macroscopic organization of the weathering profile.

733

734 Fig. 3. Chondrite-normalized (McDonough and Sun, 1995) multi-element patterns for 735 orthogneiss and main constituents of the coarse saprolite (for acronyms, see Table 4).

736

737 Fig. 4. Chondrite-normalized (McDonough and Sun, 1995) rare-earth element patterns for 738 orthogneiss.

739

740 Fig. 5. X-ray diffraction spectra for Mn-bearing phase of several grains from the black plates, 741 indicating good peaks for birnessite and cryptomelane groups, as well as quartz.

742

743 Fig. 6. Parent rock-normalized multi-element patterns for the coarse saprolite (for acronyms, 744 see Table 4).

745

746 Fig. 7. Harker diagrams of selected major and trace elements.

747

748 Fig. 8. Scattergrams of $\mathrm{Fe}_{2} \mathrm{O}_{3}$ with selected ferromagnesian trace elements: $\mathrm{A} . \mathrm{Fe}_{2} \mathrm{O}_{3}$ vs. Cr; 749 B. $\mathrm{Fe}_{2} \mathrm{O}_{3}$ vs. Ni; C. $\mathrm{Fe}_{2} \mathrm{O}_{3}$ vs. $\mathrm{Co}$; D. $\mathrm{Fe}_{2} \mathrm{O}_{3}$ vs. V. 
751 Fig. 9. Scattergrams of $\mathrm{Zr}$ with selected trace elements: A. Zirconium vs. vanadium; B.

752 Zirconium vs. hafnium; C. Zirconium vs. niobium; D. Zirconium vs. molybdenum; E.

753 Zirconium vs. thorium; F. Zirconium vs. uranium.

754

755 Fig. 10. Scattergram of light rare-earth elements (LREE) with heavy rare-earth elements 756 (HREE).

757

758 Fig. 11. Scattergrams of selected rare-earth elements with $\mathrm{Zr}$, $\mathrm{Pb}$ and rare-earth elements: A.

759 Cerium vs. zirconium; B. Cerium vs. lead; C. Cerium vs. light rare-earth elements; D. Sum of

760 Total rare-earth element (REE) content vs. cerium; E. Three lanthanide (Ce, La and Nd)

761 content vs. total rare-earth element (REE) content; F. Strontium vs. europium.

762

763 Fig. 12. A. Parent rock-normalized rare-earth element patterns for the coarse saprolite. B.

764 Chondrite-normalized (McDonough and Sun, 1995) rare-earth element patterns for the coarse 765 saprolite (for acronyms, see Table 5).

766

767 Fig. 13. BSE image of a grain displaying cyclic growth patterns in sample. The EDS spectra

768 are shown for the Mn-bearing phase (bright contrast) and the aluminosilicate phase (dark-grey

769 contrast). Several Ce-oxides grains (very bright contrast, each approximately 1 to 10 microns

770 in diameter) appear marginal to the sample as indicated.

771

772 Fig. 14. BSE image of the Mn-bearing phase with a blow-out picture of Ce-oxide marginal to

773 the sample (lower left) and a blow-out picture of the Mn-bearing phase intergrowth with the

774 aluminosilicate phase (upper right).

775 
776

777

778

779

780

781

782

783

784

785

786

787

788
Fig. 15. BSE image displaying the intergrowth of the Mn-bearing phase with the aluminosilicate phase.

.

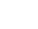

Positive Eu-anomalies in all weathered samples.

Negative Ce-anomalies in the loose and iron duricrust samples, and positive one in the kaolinitic white veins.

High $\mathrm{Mn}, \mathrm{Co}, \mathrm{Ba}, \mathrm{Zr}, \mathrm{Pb}$ and $\mathrm{Ce}$ contents in the Mn-bearing phases. Strong positive Ce-anomaly is observed.

Strong depletion of several elements in the loose and iron duricrust sapmles. 
Table 1

Mineralogical composition of the parent rock and the main constituents of the coarse saprolite.

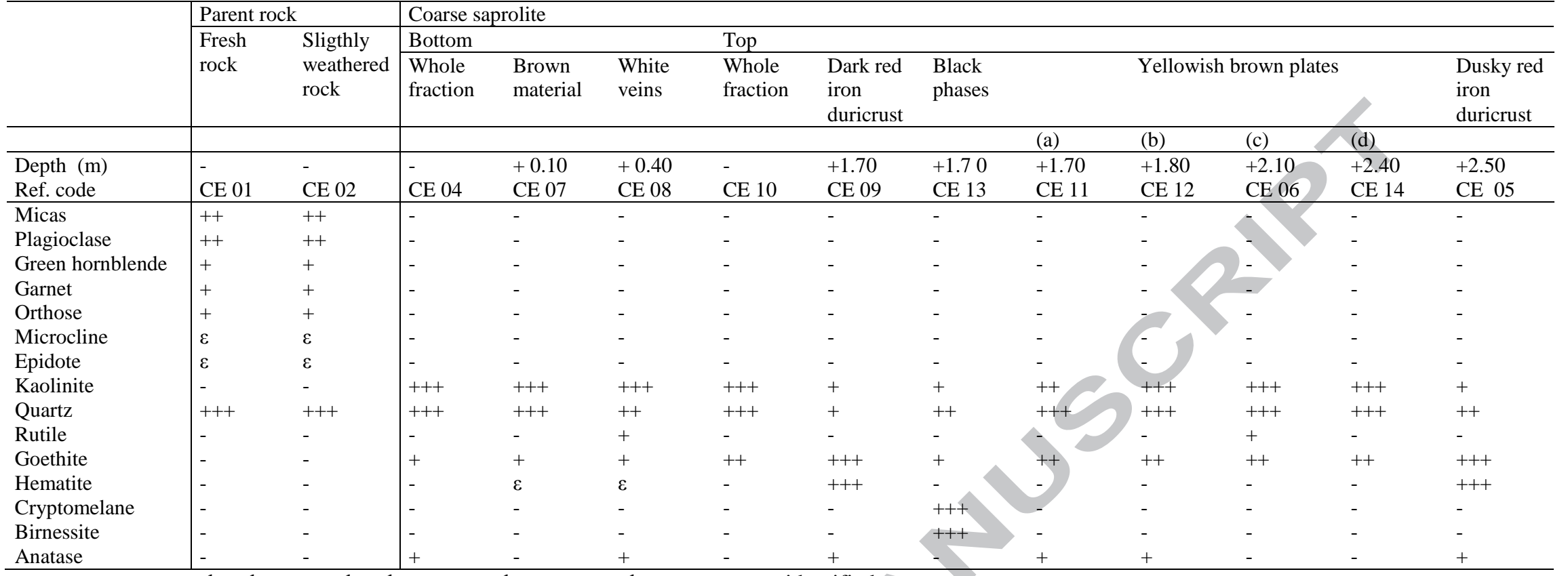

+++: very abundant; ++: abundant; +: poorly represented; $\varepsilon$ : trace; -: not identified. 
Table 2

Major element composition of the parent rock and the main constituents of the coarse saprolite (\%wt of oxides).

\begin{tabular}{|c|c|c|c|c|c|c|c|c|c|c|c|c|c|c|}
\hline \multirow[t]{4}{*}{ 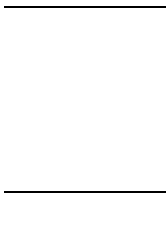 } & \multirow[t]{3}{*}{ d.l. } & \multicolumn{2}{|l|}{ Parent rock } & \multicolumn{11}{|c|}{ Coarse saprolite } \\
\hline & & \multirow{3}{*}{$\begin{array}{l}\text { Fresh } \\
\text { material }\end{array}$} & \multirow{3}{*}{$\begin{array}{l}\text { Sligthly } \\
\text { weathered } \\
\text { material }\end{array}$} & \multicolumn{3}{|l|}{ Bottom } & \multicolumn{8}{|l|}{ Top } \\
\hline & & & & $\begin{array}{l}\text { Whole } \\
\text { fraction }\end{array}$ & $\begin{array}{l}\text { Brown } \\
\text { material }\end{array}$ & $\begin{array}{l}\text { White } \\
\text { veins }\end{array}$ & $\begin{array}{l}\text { Whole } \\
\text { fraction }\end{array}$ & $\begin{array}{l}\text { Dark red } \\
\text { iron } \\
\text { duricrust }\end{array}$ & $\begin{array}{l}\text { Mn- } \\
\text { phases }\end{array}$ & & llowish b & n plates & & $\begin{array}{l}\text { Dusky red } \\
\text { iron } \\
\text { duricrust }\end{array}$ \\
\hline & & & & & & & & & & (a) & (b) & (c) & (d) & \\
\hline Depth (m) & - & - & & & +0.10 & +0.40 & - & +1.70 & +1.70 & +1.70 & +1.80 & +2.10 & +2.40 & +2.50 \\
\hline Ref. code & - & CE 01 & CE 02 & CE 04 & CE 07 & CE 08 & CE 10 & CE 09 & CE 13 & CE 11 & CE 12 & CE 06 & CE 14 & CE 05 \\
\hline $\mathrm{SiO}_{2}$ & 0.01 & 61.56 & 61.84 & 61.80 & 61.25 & 64.83 & 58.03 & 26.70 & 27.97 & 56.10 & 57.01 & 59.05 & 60.30 & 30.79 \\
\hline $\mathrm{Al}_{2} \mathrm{O}_{3}$ & 0.01 & 14.34 & 15.63 & 22.34 & 22.48 & 22.76 & 22.18 & 10.04 & 12.16 & 22.02 & 22.90 & 23.96 & 21.48 & 11.90 \\
\hline $\mathrm{Fe}_{2} \mathrm{O}_{3}$ & 0.01 & 7.06 & 6.66 & 5.12 & 5.41 & 2.26 & 7.68 & 53.26 & 10.08 & 8.63 & 6.46 & 4.80 & 6.74 & 45.60 \\
\hline $\mathrm{MnO}$ & 0.01 & 0.13 & 0.11 & 0.01 & 0.01 & 0.01 & 0.01 & 0.01 & 33.86 & 0.01 & 0.01 & 0.01 & 0.01 & 0.01 \\
\hline $\mathrm{MgO}$ & 0.01 & 4.40 & 2.92 & $<\mathrm{dl}$ & $<\mathrm{dl}$ & $<\mathrm{dl}$ & 0.01 & 0.04 & 0.15 & 0.09 & 0.08 & $<\mathrm{dl}$ & 0.01 & 0.04 \\
\hline $\mathrm{CaO}$ & 0.01 & 4.71 & 3.64 & 0.03 & 0.02 & 0.02 & 0.02 & 0.02 & 0.03 & 0.02 & 0.02 & 0.02 & 0.02 & 0.02 \\
\hline $\mathrm{Na}_{2} \mathrm{O}$ & 0.01 & 2.72 & 2.58 & $<\mathrm{dl}$ & $<\mathrm{dl}$ & $<\mathrm{dl}$ & 0.02 & $<\mathrm{dl}$ & 0.11 & 0.02 & 0.02 & $<\mathrm{dl}$ & 0.02 & $<\mathrm{dl}$ \\
\hline $\mathrm{K}_{2} \mathrm{O}$ & 0.01 & 2.81 & 3.15 & 0.04 & 0.03 & 0.04 & 0.03 & 0.01 & 0.32 & 0.02 & 0.02 & 0.04 & 0.05 & 0.01 \\
\hline $\mathrm{TiO}_{2}$ & 0.01 & 0.91 & 1.07 & 1.35 & 1.36 & 1.46 & 1.42 & 0.78 & 0.16 & 1.50 & 1.46 & 1.52 & 1.02 & 0.67 \\
\hline $\mathrm{P}_{2} \mathrm{O}_{5}$ & 0.01 & 0.23 & 0.28 & 0.09 & 0.09 & 0.08 & 0.07 & 0.03 & 0.03 & 0.05 & 0.06 & 0.10 & 0.09 & 0.10 \\
\hline LOI & 0.05 & 0.43 & 1.64 & 9.37 & 9.38 & 9.23 & 9.97 & 8.93 & 12.41 & 10.45 & 10.64 & 10.17 & 9.60 & 10.24 \\
\hline Total & & 99.30 & 99.52 & 100.15 & 100.03 & 100.69 & 99.44 & 99.82 & 97.28 & 98.91 & 98.68 & 99.67 & 97.28 & 99.38 \\
\hline $\mathrm{SiO}_{2} / \mathrm{Al}_{2} \mathrm{O}_{3}$ & - & 4.29 & 3.96 & 2.77 & 2.72 & 2.85 & 2.62 & 2.66 & 2.30 & 2.55 & 2.49 & 2.46 & 2.81 & 2.59 \\
\hline $\mathrm{Fe}_{2} \mathrm{O}_{3} / \mathrm{K}_{2} \mathrm{O}$ & - & 2.51 & 2.11 & 1.28 & 180.33 & 56.50 & 256.00 & 5326.00 & 31.50 & 431.50 & 323.00 & 120.00 & 134.80 & 4560.00 \\
\hline
\end{tabular}

d.1.: detection limits.

Note that the $\mathrm{BaO}$ content is 4.30 wt.\% in the $\mathrm{Mn}$-phases.

Ref. code: reference code. 
Table 3

Bulk density and porosity (in \%) of the parent rock and the main constituents of the coarse saprolite.

\begin{tabular}{|c|c|c|c|c|c|c|c|c|c|c|c|c|}
\hline & \multicolumn{2}{|c|}{ Parent rock } & \multicolumn{10}{|c|}{ Coarse saprolite } \\
\hline & \multirow{3}{*}{$\begin{array}{l}\text { Fresh } \\
\text { rock }\end{array}$} & \multirow{2}{*}{$\begin{array}{l}\text { Sligthly } \\
\text { weathered } \\
\text { rock }\end{array}$} & \multicolumn{3}{|l|}{ Bottom } & \multicolumn{7}{|l|}{ Top } \\
\hline & & & $\begin{array}{l}\text { Whole } \\
\text { fraction }\end{array}$ & $\begin{array}{l}\text { Brown } \\
\text { material }\end{array}$ & $\begin{array}{l}\text { White } \\
\text { veins }\end{array}$ & $\begin{array}{l}\text { Whole } \\
\text { fraction }\end{array}$ & $\begin{array}{l}\text { Dark red } \\
\text { iron } \\
\text { duricrust }\end{array}$ & Mn-phases & & ellowish brown plates & & $\begin{array}{l}\text { Dusky red } \\
\text { iron } \\
\text { duricrust }\end{array}$ \\
\hline & & & & & & & & & (a) & (c) & (d) & \\
\hline Depth (m) & & & & +0.10 & +0.40 & & +1.70 & +1.70 & +1.70 & +1.80 & +2.40 & +2.50 \\
\hline Ref. code & CE 01 & CE 02 & CE 04 & CE 07 & CE 08 & CE 10 & CE 09 & CE 13 & CE 11 & CE 12 & CE 14 & CE 05 \\
\hline Bulk density & 2.01 & 2.06 & 1.28 & 0.93 & 1.10 & 1.38 & 2.53 & 2.36 & 1.42 & 1.32 & 1.29 & 1.66 \\
\hline Porosity & 27.69 & 25.09 & 50.38 & 35.22 & 46.41 & 45.01 & 22.86 & 27.00 & 47.00 & 49.00 & 50.00 & 36.72 \\
\hline
\end{tabular}


Table 4

Trace element composition of the parent rock and the main constituents of the coarse saprolite (ppm).

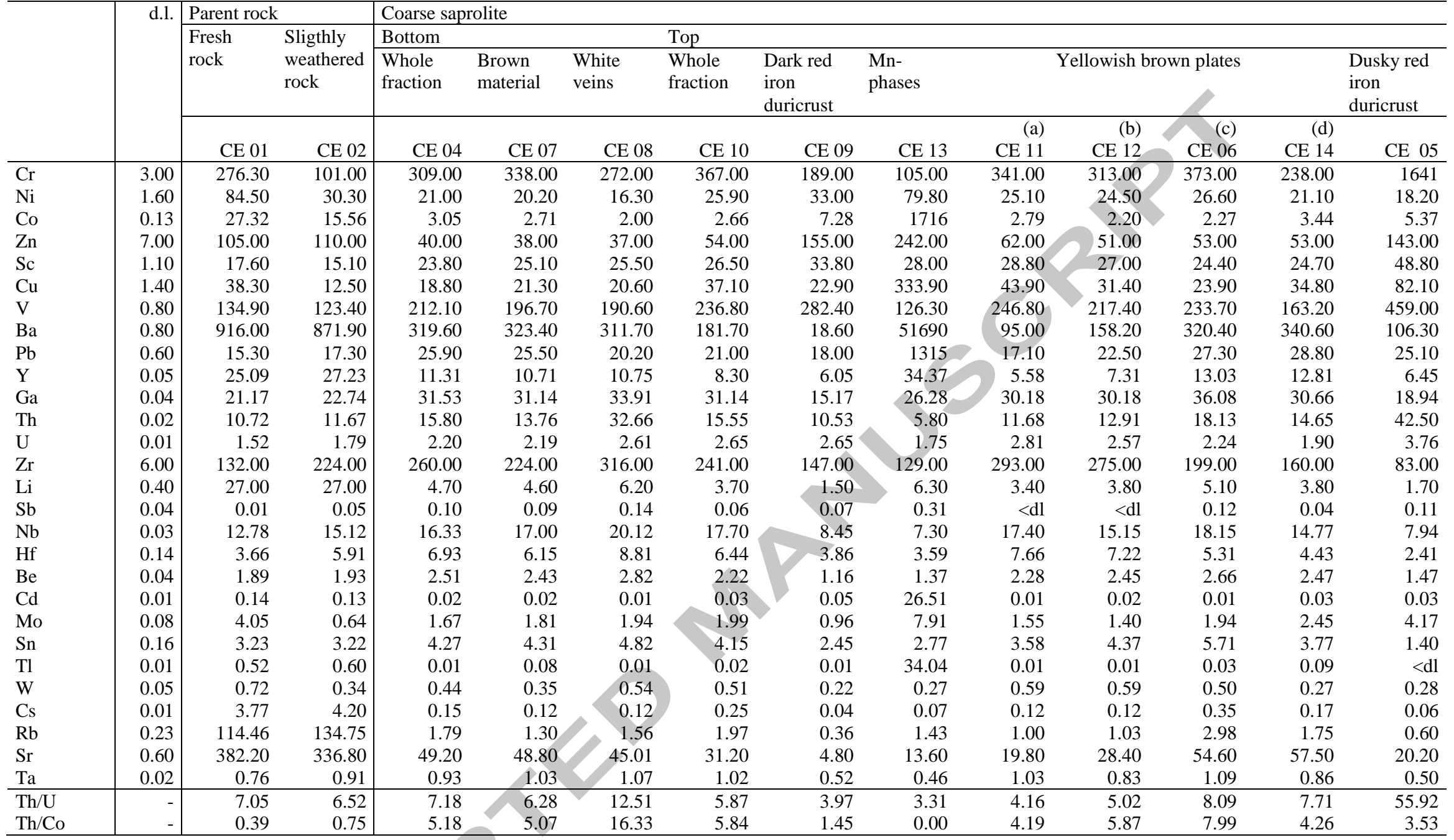

d.1.: detection limits. 
Table 5

Rare-earth element composition of the parent rock and the main constituents of the coarse saprolite (ppm).

\begin{tabular}{|c|c|c|c|c|c|c|c|c|c|c|c|c|c|c|}
\hline \multirow[t]{5}{*}{$\overline{\mathrm{REE}}$} & \multirow[t]{5}{*}{ d.l. } & \multicolumn{2}{|c|}{ Parent rock } & \multicolumn{11}{|c|}{ Coarse saprolite } \\
\hline & & \multirow{3}{*}{$\begin{array}{l}\text { Fresh } \\
\text { rock }\end{array}$} & \multirow{2}{*}{$\begin{array}{l}\text { Sligthly } \\
\text { weathered } \\
\text { rock }\end{array}$} & \multicolumn{3}{|l|}{ Bottom } & \multicolumn{8}{|l|}{ Top } \\
\hline & & & & $\begin{array}{l}\text { Whole } \\
\text { fraction }\end{array}$ & $\begin{array}{l}\text { Brown } \\
\text { material }\end{array}$ & $\begin{array}{l}\text { White } \\
\text { veins }\end{array}$ & $\begin{array}{l}\text { Whole } \\
\text { fraction }\end{array}$ & $\begin{array}{l}\text { Dark red } \\
\text { iron } \\
\text { duricrust }\end{array}$ & $\begin{array}{l}\text { Mn- } \\
\text { phases }\end{array}$ & & llowish br & wn plates & & $\begin{array}{l}\text { Dusky red } \\
\text { iron } \\
\text { duricrust }\end{array}$ \\
\hline & & & & & & & & & & (a) & (b) & (c) & (d) & \\
\hline & & CE 01 & CE 02 & CE 04 & CE 07 & CE 08 & CE 10 & CE 09 & CE 13 & CE 11 & CE 12 & CE 06 & CE 14 & CE 05 \\
\hline $\mathrm{La}$ & 0.04 & 43.04 & 44.92 & 23.95 & 24.63 & 20.61 & 17.47 & 4.57 & 166.89 & 10.91 & 14.56 & 25.76 & 22.48 & 8.34 \\
\hline $\mathrm{Ce}$ & 0.12 & 87.02 & 86.86 & 35.92 & 33.31 & 117.58 & 27.00 & 9.15 & 5,202 & 17.15 & 21.77 & 39.54 & 33.40 & 12.62 \\
\hline $\operatorname{Pr}$ & 0.01 & 10.54 & 10.55 & 4.41 & 4.39 & 3.58 & 3.72 & 2.27 & 40.06 & 2.48 & 3.15 & 5.33 & 4.47 & 2.63 \\
\hline $\mathrm{Nd}$ & 0.06 & 40.79 & 41.32 & 16.79 & 16.86 & 13.58 & 14.20 & 9.40 & 123.75 & 9.61 & 12.66 & 20.81 & 17.42 & 10.87 \\
\hline $\mathrm{Sm}$ & 0.01 & 7.86 & 7.60 & 4.08 & 4.20 & 3.34 & 3.39 & 3.04 & 26.68 & 2.42 & 3.20 & 5.07 & 4.46 & 3.28 \\
\hline $\mathrm{Eu}$ & 0.03 & 1.56 & 1.56 & 1.08 & 1.11 & 0.90 & 0.88 & 0.70 & 9.092 & 0.64 & 0.88 & 1.30 & 1.25 & 0.80 \\
\hline $\mathrm{Gd}$ & 0.01 & 6.21 & 6.15 & 3.88 & 4.16 & 3.49 & 3.06 & 2.26 & 15.45 & 2.09 & 2.91 & 4.62 & 4.44 & 2.50 \\
\hline $\mathrm{Tb}$ & 0.002 & 0.88 & 0.89 & 0.56 & 0.61 & 0.53 & 0.44 & 0.45 & 3.21 & 0.32 & 0.43 & 0.67 & 0.64 & 0.43 \\
\hline Dy & 0.01 & 4.91 & 5.25 & 3.12 & 3.24 & 2.84 & 2.48 & 2.79 & 17.18 & 1.82 & 2.37 & 3.59 & 3.62 & 2.58 \\
\hline Ho & 0.003 & 0.91 & 0.98 & 0.51 & 0.52 & 0.49 & 0.41 & 0.49 & 3.08 & 0.30 & 0.37 & 0.61 & 0.61 & 0.44 \\
\hline Er & 0.01 & 2.50 & 2.66 & 1.20 & 1.21 & 1.17 & 1.00 & 1.48 & 9.45 & 0.74 & 0.90 & 1.47 & 1.42 & 1.24 \\
\hline $\mathrm{Tm}$ & 0.002 & 0.35 & 0.37 & 0.14 & 0.14 & 0.14 & 0.13 & 0.25 & 1.63 & 0.10 & 0.12 & 0.18 & 0.17 & 0.20 \\
\hline $\mathrm{Yb}$ & 0.01 & 2.22 & 2.29 & 0.80 & 0.78 & 0.83 & 0.86 & 1.95 & 12.40 & 0.70 & 0.74 & 1.05 & 0.96 & 1.42 \\
\hline $\mathrm{Lu}$ & 0.002 & 0.32 & 0.33 & 0.10 & 0.09 & 0.11 & 0.11 & 0.26 & 1.75 & 0.09 & 0.09 & 0.13 & 0.12 & 0.19 \\
\hline$\Sigma$ REE & - & 209.10 & 211.73 & 96.56 & 95.24 & 169.17 & 75.16 & 39.06 & 5632.61 & 49.38 & 64.15 & 110.13 & 95.45 & 47.53 \\
\hline$\Sigma$ LREE & - & 190.81 & 192.81 & 86.23 & 84.51 & 159.59 & 66.66 & 29.14 & 5568.48 & 43.22 & 56.22 & 97.81 & 83.48 & 38.53 \\
\hline$\Sigma$ HREE & - & 18.29 & 18.92 & 10.34 & 10.73 & 9.59 & 8.50 & 9.92 & 64.13 & 6.16 & 7.92 & 12.32 & 11.10 & 8.99 \\
\hline a. & - & 10.44 & 10.19 & 8.34 & 7.87 & 16.65 & 7.84 & 2.94 & 86.83 & 7.01 & 7.09 & 7.94 & 6.97 & 4.28 \\
\hline $\mathrm{Ce} / \mathrm{Ce}^{*}(1)$ & - & 0.99 & 0.97 & - & - & - & & - & - & - & - & - & - & - \\
\hline $\mathrm{Eu} / \mathrm{Eu}^{*}{ }^{*}(1)$ & - & 0.68 & 0.69 & - & - & - & & - & - & - & - & - & - & - \\
\hline $\mathrm{Ce} / \mathrm{Ce}^{*}(2)$ & - & - & & 0.86 & 0.78 & 3.35 & 0.82 & 0.69 & 15.57 & 0.81 & 0.79 & 0.83 & 0.82 & 0.66 \\
\hline $\mathrm{Eu} / \mathrm{Eu}^{*}(2)$ & - & - & - & 1.22 & 1.19 & 1.18 & 1.23 & 1.20 & 2.01 & 1.40 & 1.30 & 1.20 & 1.25 & 1.25 \\
\hline$(\mathrm{La} / \mathrm{Yb})_{\mathrm{N}}$ & - & 13.19 & 13.35 & 1.51 & 1.63 & 1.29 & 1.05 & 0.12 & 0.69 & 0.80 & 1.02 & 1.26 & 1.21 & 0.30 \\
\hline
\end{tabular}

d.l.: detection limits.

a. $=$ LREE/ HREE.

$\mathrm{Ce}$ anomaly $=\left(\mathrm{Ce} / \mathrm{Ce}^{*}\right)(1)=\left(\mathrm{Ce}_{\text {orthogneiss }} / \mathrm{Ce}\right.$ chondrite $) /(\mathrm{La} \text { orthogneiss } / \mathrm{La} \text { chondrite })^{0.5}\left(\mathrm{Pr}_{\text {orthogneiss }} / \mathrm{Pr}_{\text {chondrite }}\right)^{0.5}$.

Eu anomaly $=\left(\mathrm{Eu}^{\mathrm{E}} / \mathrm{Eu}^{*}\right)(1)=\left(\mathrm{Eu}_{\text {orthogniess }} / \mathrm{Eu}_{\text {chondrite }}\right) /\left(\mathrm{Sm}_{\text {orthogniess }} / \mathrm{Sm}_{\text {chondrite }}\right)^{0.5}\left(\mathrm{Gd}_{\text {orthogneiss }} / \mathrm{Gd}_{\mathrm{c} \text { hondrite }}\right)^{0.5}$.

Ce anomaly $=\left(\mathrm{Ce} / \mathrm{Ce}^{*}\right)(2)=\left(\mathrm{Ce}_{\text {weathered sample }} \mathrm{Ce}\right.$ orthogneiss $) /\left(\mathrm{La}_{\text {weathered sample }} / \mathrm{La} \text { orthogneiss }\right)^{0.5}\left(\mathrm{Pr}_{\text {weathered sample }} / \mathrm{Pr}_{\text {orthogneiss }}\right)^{0.5}$

$\mathrm{Eu}$ anomaly $=\left(\mathrm{Eu} / \mathrm{Eu}^{*}\right)(2)=\left(\mathrm{Eu}_{\text {weathered sampe }} / \mathrm{Eu}_{\text {orthogneiss }}\right) /\left(\mathrm{Sm}_{\text {weathered sample }} / \mathrm{Sm} \text { orthogneiss }\right)^{0.5}\left(\mathrm{Gd}_{\text {weathered sample }} / \mathrm{Gd}_{\text {orthogneiss }}\right)^{0.5}$.

For rock samples: $(\mathrm{La} / \mathrm{Yb})_{\mathrm{N}}=\left(\mathrm{La}_{\text {orthogneis }} / \mathrm{La} \mathrm{a}_{\text {chondrite }}\right) /(\mathrm{Yb}$ orthogneiss $/ \mathrm{Yb}$ chondrite $)$.

For weathered samples: $(\mathrm{La} / \mathrm{Yb})_{\mathrm{N}}=\left(\mathrm{La}_{\text {weathered sample }} / \mathrm{La}\right.$ orthogneiss $) /\left(\mathrm{Yb}_{\text {weathered sample }} / \mathrm{Yb}\right.$ orthogneiss $)$. 
Table 6

Geochemical balance evaluation of major elements in the coarse saprolite by isovolumetric method (\%).

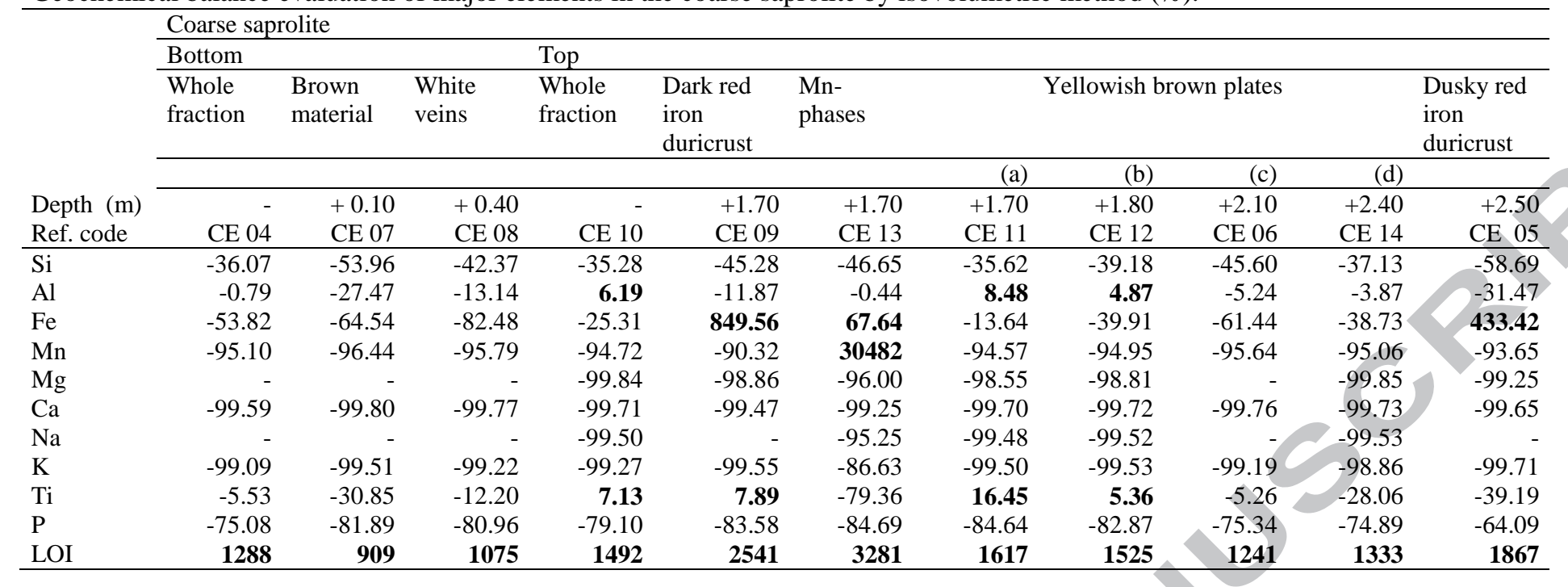


Table 7

Geochemical balance evaluation of trace elements in the coarse saprolite by isovolumetric method (\%).

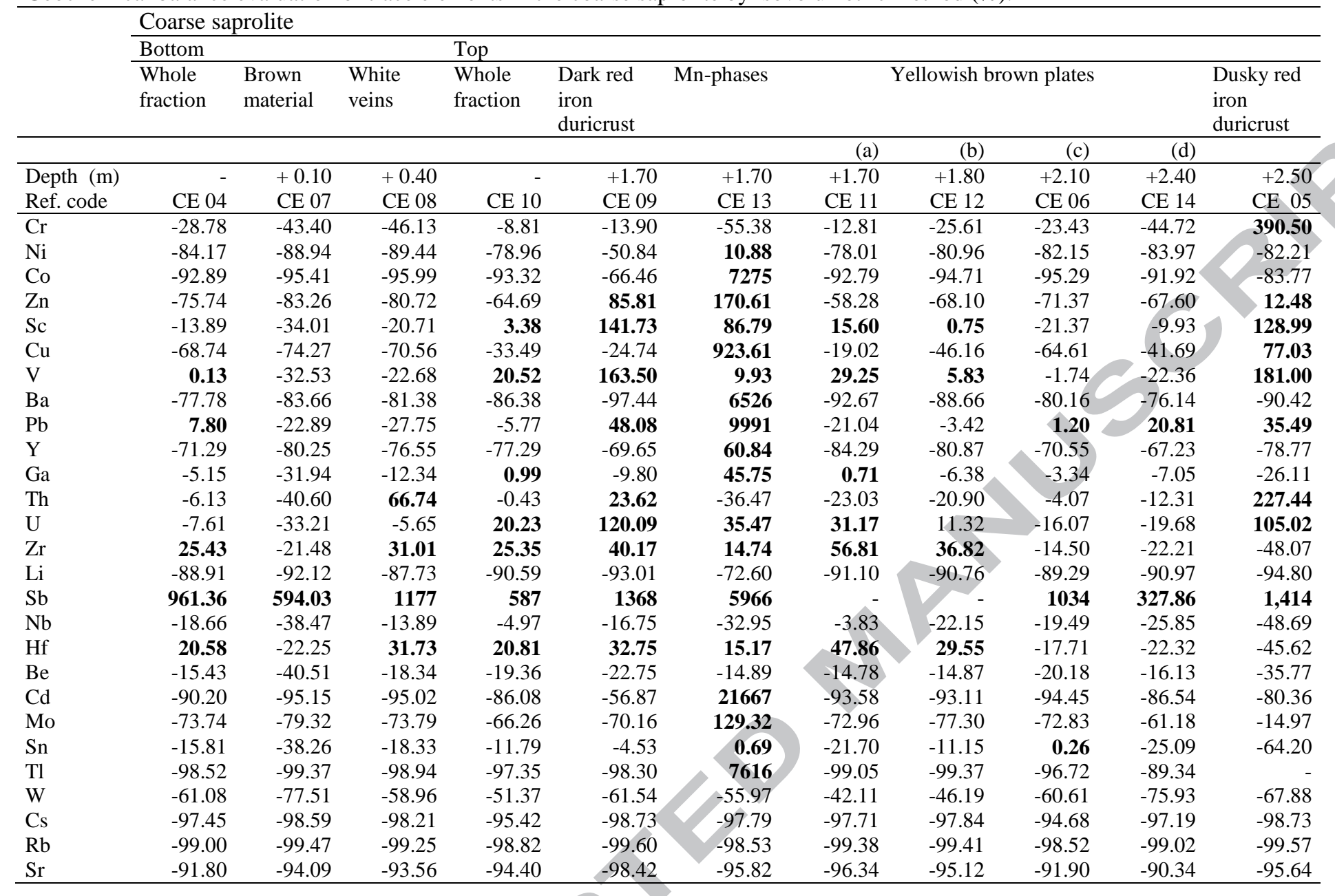


Table 8

Geochemical balance evaluation of rare-earth elements in the coarse saprolite by isovolumetric method (\%).

\begin{tabular}{|c|c|c|c|c|c|c|c|c|c|c|c|}
\hline & \multicolumn{11}{|c|}{ Coarse saprolite } \\
\hline & \multicolumn{3}{|l|}{ Bottom } & \multicolumn{8}{|l|}{ Top } \\
\hline & $\begin{array}{l}\text { Whole } \\
\text { fraction }\end{array}$ & $\begin{array}{l}\text { Brown } \\
\text { material }\end{array}$ & $\begin{array}{l}\text { White } \\
\text { veins }\end{array}$ & $\begin{array}{l}\text { Whole } \\
\text { fraction }\end{array}$ & $\begin{array}{l}\text { Dark red } \\
\text { iron } \\
\text { duricrust }\end{array}$ & $\begin{array}{l}\text { Mn- } \\
\text { phases }\end{array}$ & & llowish b & vn plates & & $\begin{array}{l}\text { Dusky red } \\
\text { iron } \\
\text { duricrust }\end{array}$ \\
\hline & & & & & & & (a) & (b) & (c) & (d) & \\
\hline Depth (m) & - & +0.10 & +0.40 & - & +1.70 & +1.70 & +1.70 & +1.80 & +2.10 & +2.40 & +2.50 \\
\hline Ref. code & CE 04 & CE 07 & CE 08 & CE 10 & CE 09 & CE 13 & CE 11 & CE 12 & CE 06 & CE 14 & CE 05 \\
\hline $\mathrm{La}$ & -64.56 & -73.52 & -73.79 & -72.13 & -86.64 & 355.28 & -82.09 & -77.78 & -66.05 & -66.48 & -84.00 \\
\hline $\mathrm{Ce}$ & -73.71 & -82.29 & -26.05 & -78.70 & -86.76 & 6919 & -86.08 & -83.57 & -74.23 & -75.37 & -88.02 \\
\hline $\operatorname{Pr}$ & -73.37 & -80.73 & -81.43 & -75.81 & -72.85 & 346.26 & -83.37 & -80.36 & -71.35 & -72.79 & -79.43 \\
\hline $\mathrm{Nd}$ & -73.79 & -80.99 & -81.78 & -76.10 & -70.99 & 256.21 & -83.36 & -79.62 & -71.06 & -72.59 & -77.99 \\
\hline Sm & -66.98 & -75.26 & -76.76 & -70.36 & -51.28 & 298.58 & -78.22 & -73.26 & -63.39 & -63.58 & -65.56 \\
\hline $\mathrm{Eu}$ & -55.84 & -67.00 & -68.37 & -61.07 & -43.40 & 584.75 & -70.91 & -62.85 & -52.63 & -48.75 & -57.73 \\
\hline Gd & -60.15 & -69.02 & -69.23 & -66.10 & -54.09 & 192.26 & -76.26 & -69.25 & -57.73 & -54.08 & -66.74 \\
\hline $\mathrm{Tb}$ & -59.40 & -68.30 & -67.34 & -65.63 & -35.85 & 326.70 & -74.40 & -68.09 & -57.16 & -53.34 & -59.41 \\
\hline Dy & -59.47 & -69.49 & -68.38 & -65.37 & -28.39 & 310.93 & -73.75 & -68.29 & -58.56 & -52.62 & -56.61 \\
\hline Ho & -63.83 & -73.31 & -70.67 & -68.90 & -32.27 & 299.72 & -76.97 & -72.86 & -61.71 & -57.10 & -59.66 \\
\hline $\mathrm{Er}$ & -69.33 & -77.64 & -74.77 & -72.54 & -25.69 & 343.59 & -79.03 & -76.44 & -66.63 & -63.44 & -59.10 \\
\hline $\mathrm{Tm}$ & -74.16 & -81.89 & -77.64 & -73.91 & -9.37 & 445.47 & -79.01 & -78.23 & -71.64 & -69.56 & -53.99 \\
\hline $\mathrm{Yb}$ & -76.91 & -83.80 & -79.63 & -73.34 & 10.60 & 556.56 & -77.76 & -78.20 & -73.11 & -72.24 & -47.03 \\
\hline $\mathrm{Lu}$ & -79.31 & -86.72 & -81.01 & -75.53 & 1.25 & 547.44 & -79.05 & -80.53 & -76.74 & -76.11 & -51.80 \\
\hline
\end{tabular}


Table 9

Mass balance calculations of major elements in the coarse saprolite by isovolumetric method $\left(\mathrm{kg} / \mathrm{m}^{3}\right)$.

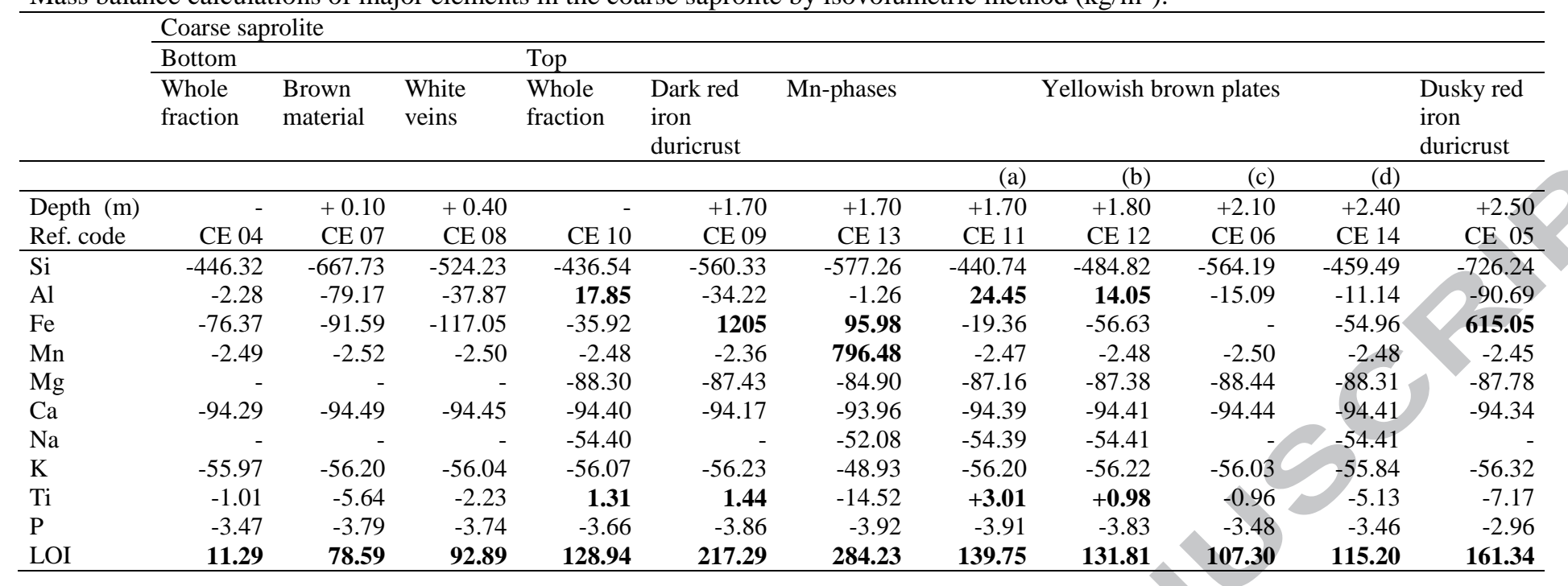


Table 10

Mass balance calculations of trace elements in the coarse saprolite by isovolumetric method $\left(\mathrm{g} / \mathrm{m}^{3}\right)$.

\begin{tabular}{|c|c|c|c|c|c|c|c|c|c|c|c|}
\hline & \multicolumn{11}{|c|}{ Coarse saprolite } \\
\hline & \multirow{3}{*}{$\begin{array}{l}\text { Bottom } \\
\text { Whole } \\
\text { fraction }\end{array}$} & \multirow{3}{*}{$\begin{array}{l}\text { Brown } \\
\text { material }\end{array}$} & \multirow{3}{*}{$\begin{array}{l}\text { White } \\
\text { veins }\end{array}$} & \multicolumn{3}{|l|}{ Тор } & \multirow{2}{*}{\multicolumn{4}{|c|}{ Yellowish brown plates }} & \multirow{2}{*}{$\begin{array}{l}\text { Dusky red } \\
\text { iron } \\
\text { duricrust }\end{array}$} \\
\hline & & & & $\begin{array}{l}\text { Whole } \\
\text { fraction }\end{array}$ & $\begin{array}{l}\text { Dark red } \\
\text { iron }\end{array}$ & $\begin{array}{l}\text { Mn- } \\
\text { phases }\end{array}$ & & & & & \\
\hline & & & & & & & (a) & (b) & (c) & (d) & \\
\hline Depth (m) & & +0.10 & +0.40 & & +1.70 & +1.70 & +1.70 & +1.80 & +2.10 & +2.40 & +2.50 \\
\hline Ref. code & CE 04 & CE 07 & CE 08 & CE 10 & CE 09 & CE 13 & CE 11 & CE 12 & CE 06 & CE 14 & CE 05 \\
\hline $\mathrm{Cr}$ & -160 & -241 & -256 & -49 & -77 & -308 & -71 & -142 & -130 & -248 & 2169 \\
\hline $\mathrm{Ni}$ & -143 & -151 & -152 & -134 & -86 & 18 & -134 & -138 & -140 & -143 & -140 \\
\hline Co & -51 & -52 & -53 & -51 & -36 & 3995 & -51 & -52 & -52 & -50 & -46 \\
\hline $\mathrm{Zn}$ & -160 & -176 & -170 & -137 & 181 & 360 & -123 & -144 & -151 & -143 & 26 \\
\hline Sc & -5 & -12 & -7 & 1 & 50 & 31 & 6 & 0 & -8 & -4 & 46 \\
\hline $\mathrm{Cu}$ & -53 & -57 & -54 & -26 & -19 & 711 & -15 & -36 & -50 & -32 & 59 \\
\hline $\mathrm{V}$ & 0 & -88 & -61 & 56 & 443 & 27 & 79 & 16 & -5 & -61 & 491 \\
\hline $\mathrm{Ba}$ & -1432 & -1540 & -1498 & -1590 & -1794 & 120147 & -1706 & -1632 & 1476 & 1402 & -1665 \\
\hline $\mathrm{Pb}$ & 2 & -7 & -9 & -2 & 15 & 3073 & -6 & -1 & 0 & 6 & +11 \\
\hline Y & -36 & -40 & -39 & -39 & -35 & 31 & -43 & -41 & -36 & -34 & -40 \\
\hline $\mathrm{Ga}$ & -2 & -14 & -5 & 0 & -4 & 19 & 0 & -3 & -1 & -3 & -11 \\
\hline Th & -1 & -9 & 14 & 0 & 5 & -8 & -5 & -5 & -1 & -3 & 49 \\
\hline $\mathrm{U}$ & 0 & -1 & 0 & 1 & 4 & 1 & 1 & 0 & 0 & -1 & +3 \\
\hline $\mathrm{Zr}$ & 67 & -57 & 82 & 67 & 107 & 39 & 51 & 98 & -38 & -59 & -128 \\
\hline $\mathrm{Li}$ & -48 & -50 & -47 & -49 & -50 & -39 & -49 & -49 & -48 & -49 & -51 \\
\hline $\mathrm{Nb}$ & -5 & -10 & -4 & -1 & -4 & -8 & -1 & -6 & -5 & -7 & -13 \\
\hline $\mathrm{Hf}$ & 2 & -2 & 2 & 2 & 2 & 1 & 4 & 2 & -1 & -2 & -3 \\
\hline $\mathrm{Be}$ & -1 & -2 & -1 & -1 & -1 & -1 & -1 & -1 & -1 & -1 & -1 \\
\hline Mo & -6 & -6 & -6 & -5 & -6 & 11 & -6 & -6 & -6 & -5 & -1 \\
\hline $\mathrm{Sn}$ & -1 & -2 & -1 & -1 & 0 & 0 & -1 & -1 & 0 & -2 & -4 \\
\hline $\mathrm{Tl}$ & -1 & 1 & -1 & -1 & -1 & 79 & -1 & -1 & -1 & -1 & - \\
\hline $\mathrm{W}$ & -1 & -1 & -1 & -1 & -1 & -1 & -1 & -1 & -1 & -1 & -1 \\
\hline Cs & -7 & -7 & -7 & -7 & -7 & & -7 & -7 & -7 & -7 & -7 \\
\hline $\mathrm{Rb}$ & -228 & -229 & -228 & -227 & -229 & 227 & -229 & -229 & -227 & -228 & -229 \\
\hline $\mathrm{Sr}$ & -705 & -723 & -719 & -725 & -756 & 736 & -740 & -731 & -706 & -694 & -735 \\
\hline
\end{tabular}


Table 11

Mass balance calculations of rare-earth elements in the coarse saprolite by isovolumetric method $\left(\mathrm{g} / \mathrm{m}^{3}\right)$.

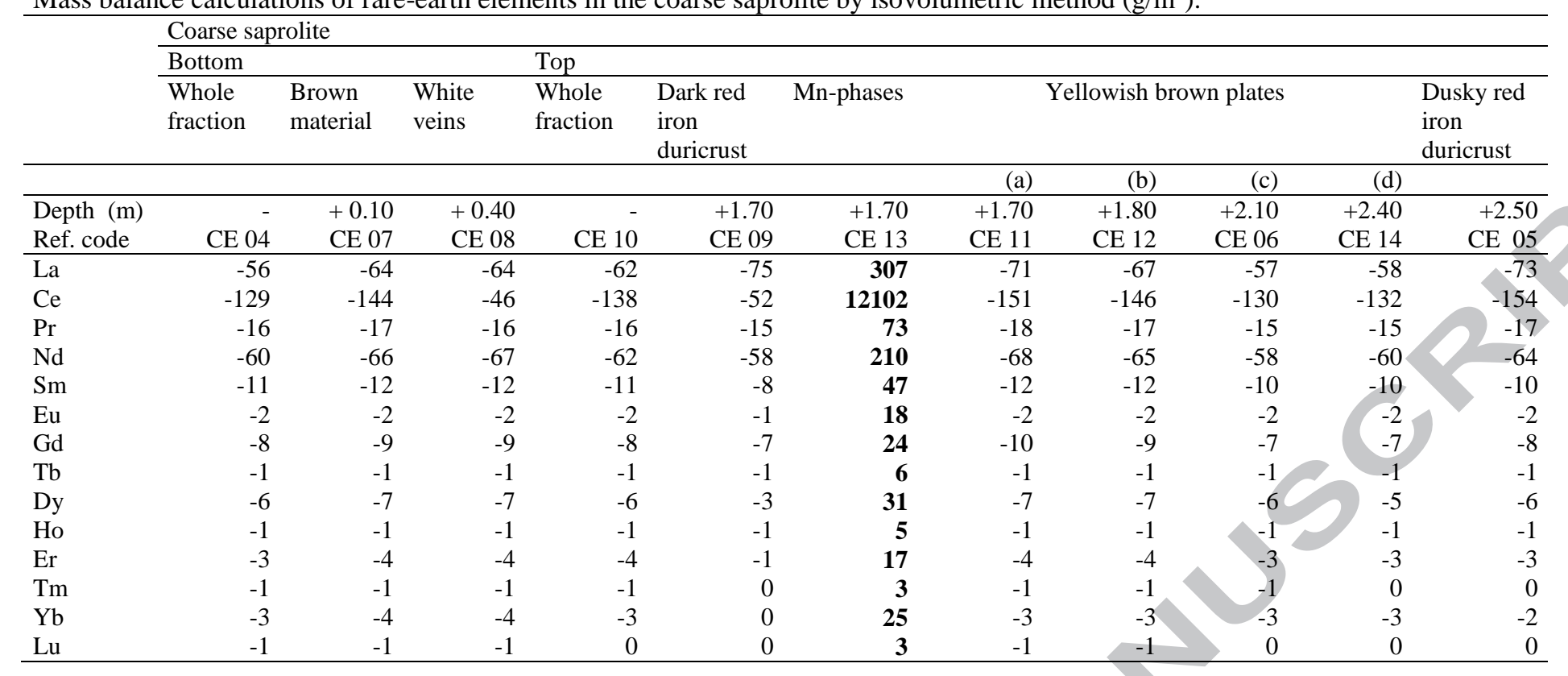




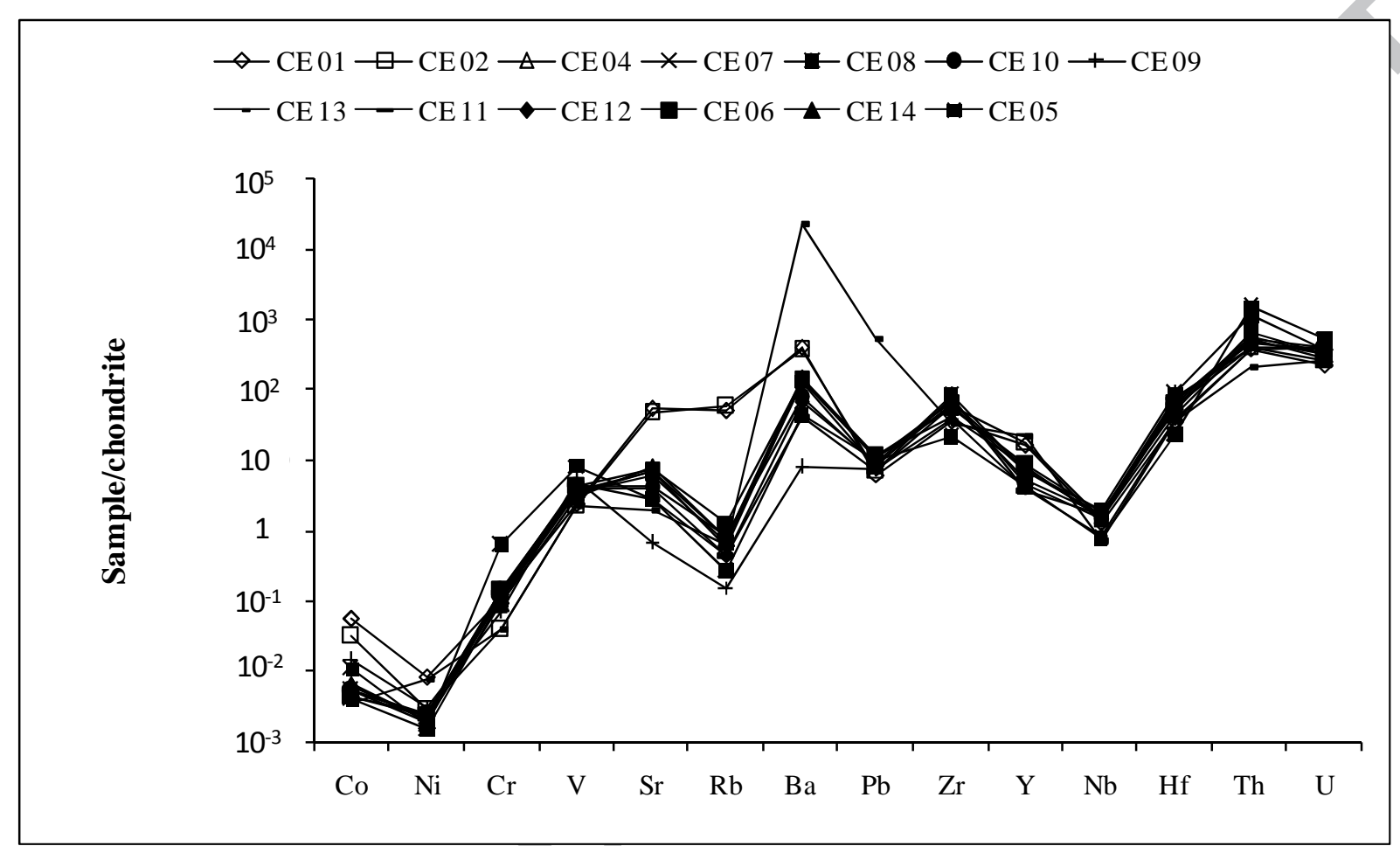

Figure 3 


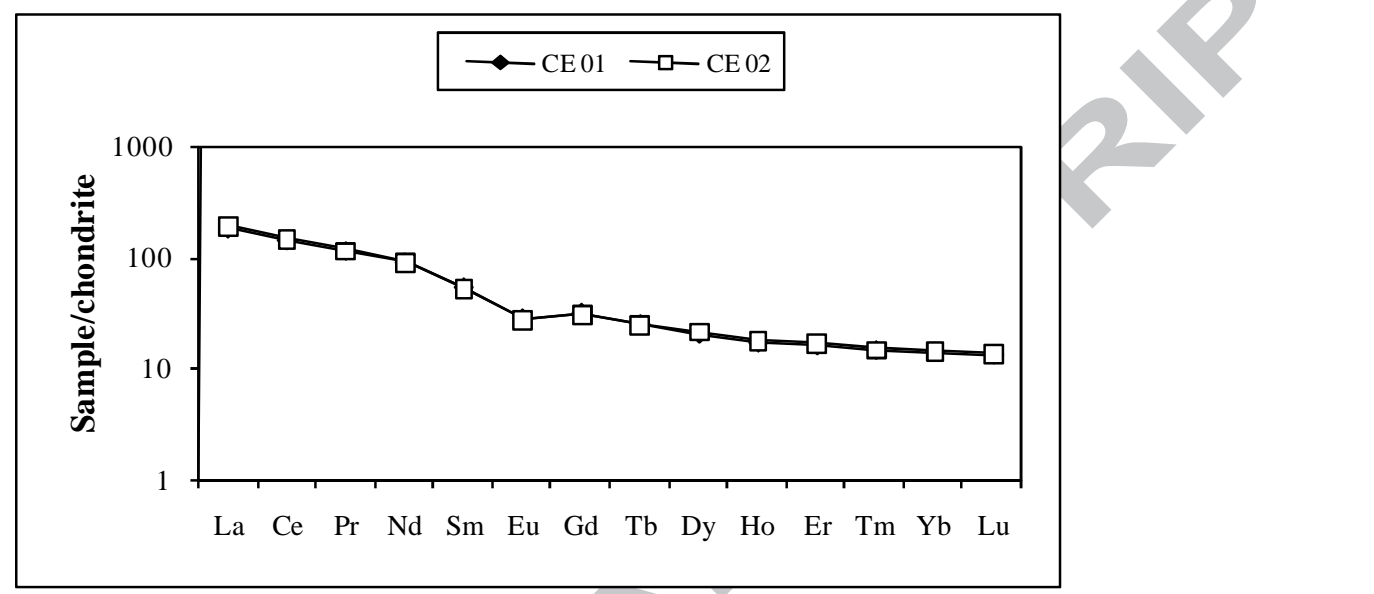

Figure 4 


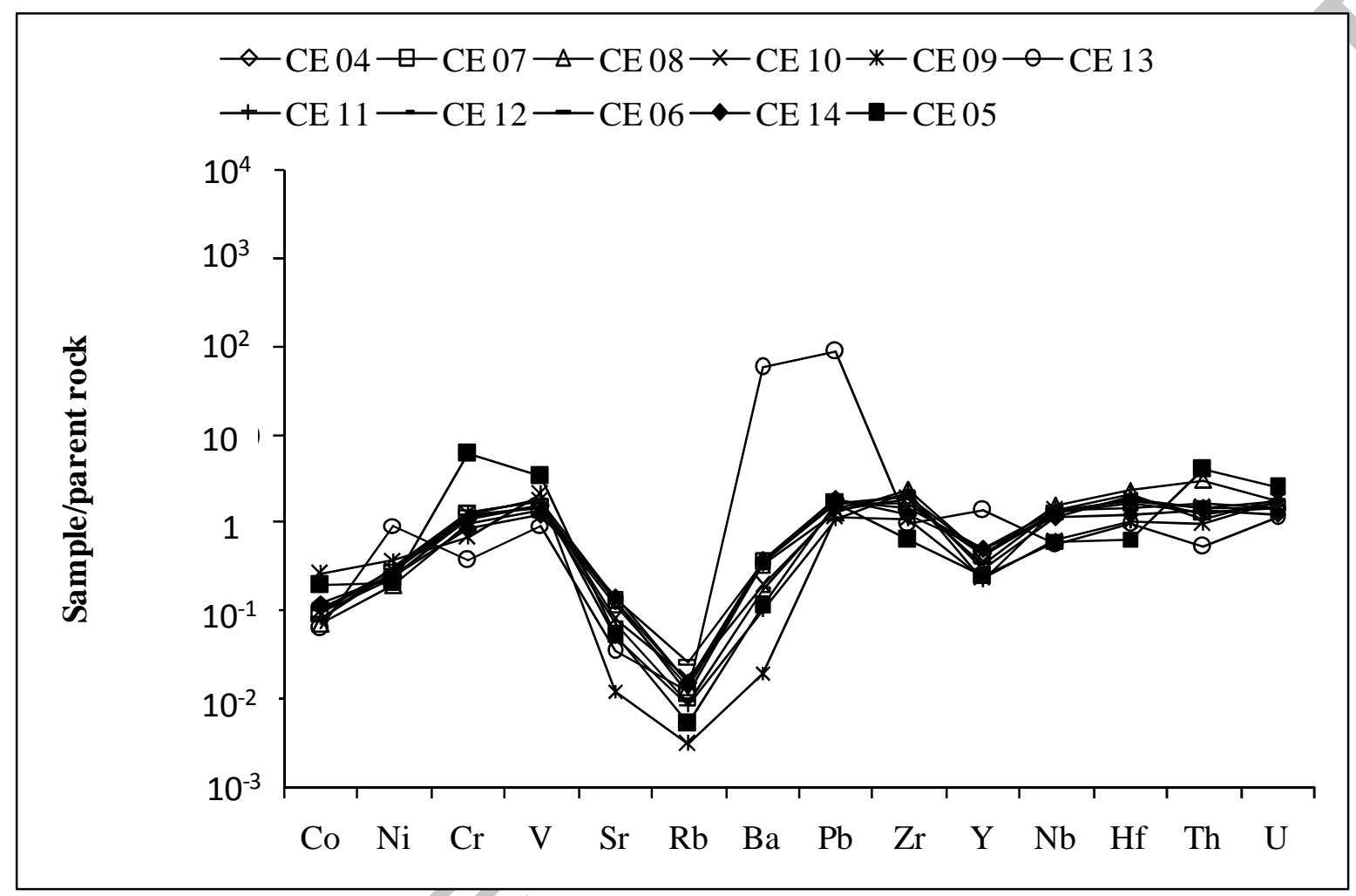

Figure 6 

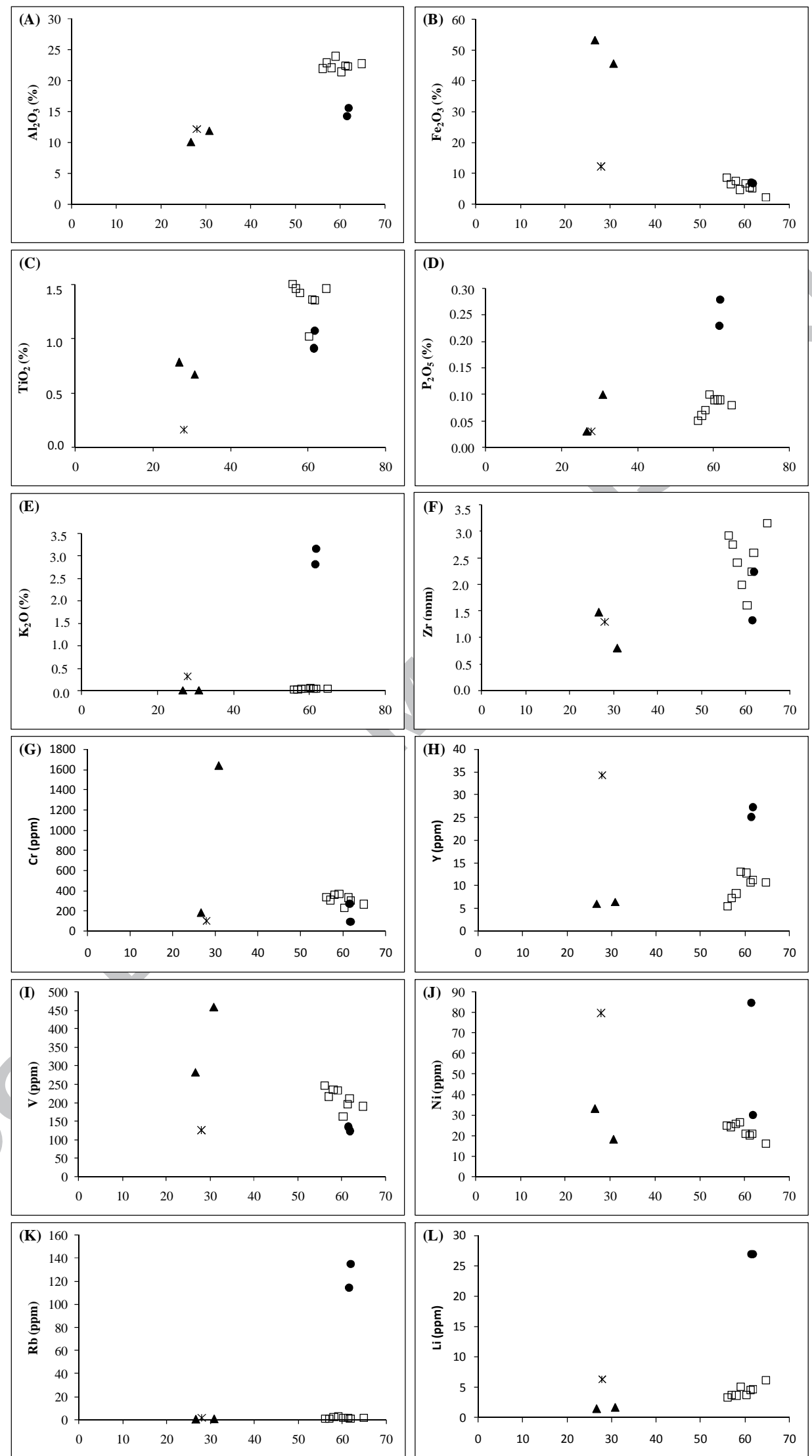

$$
\mathrm{SiO}_{2}(\%)
$$

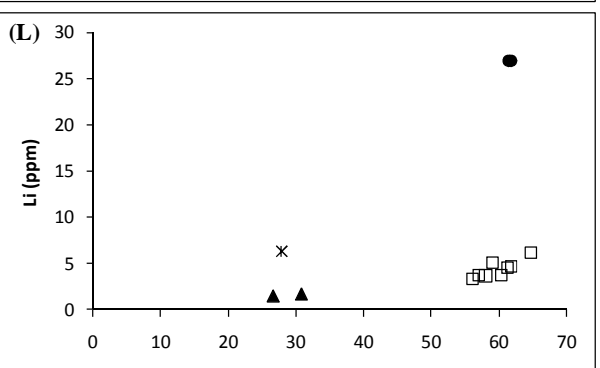

口Loose materials $\Delta$ Iron duricrust $*$ Mn-phases $\bullet$ Parent rock

Figure 7 

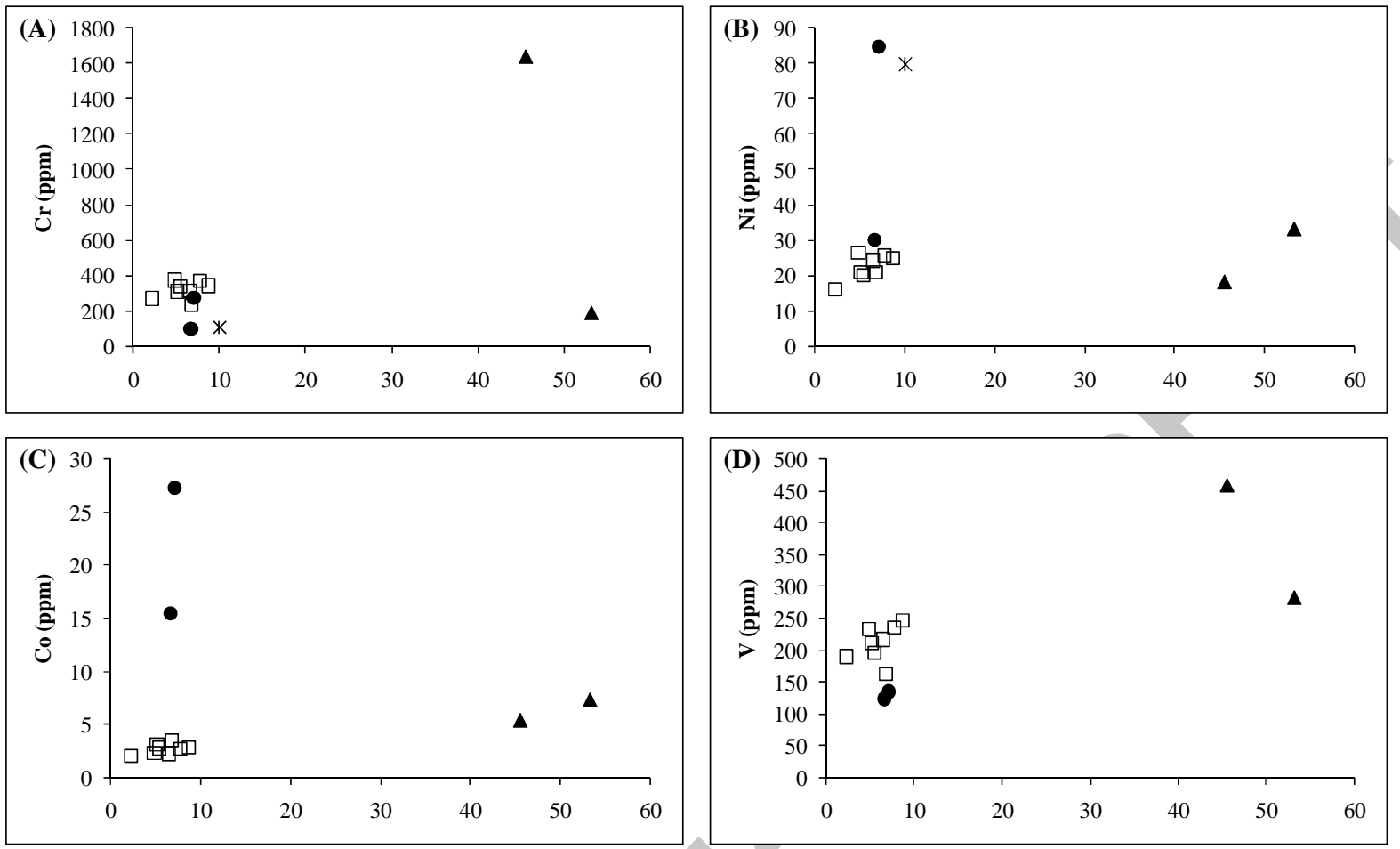

$\mathrm{Fe}_{2} \mathrm{O}_{3}(\%)$

$\mathrm{Fe}_{2} \mathrm{O}_{3}(\%)$

$\square$ Loose materials $\Delta$ Iron duricrust $*$ Mn-phases $\bullet$ Parent rock

Figure 8 

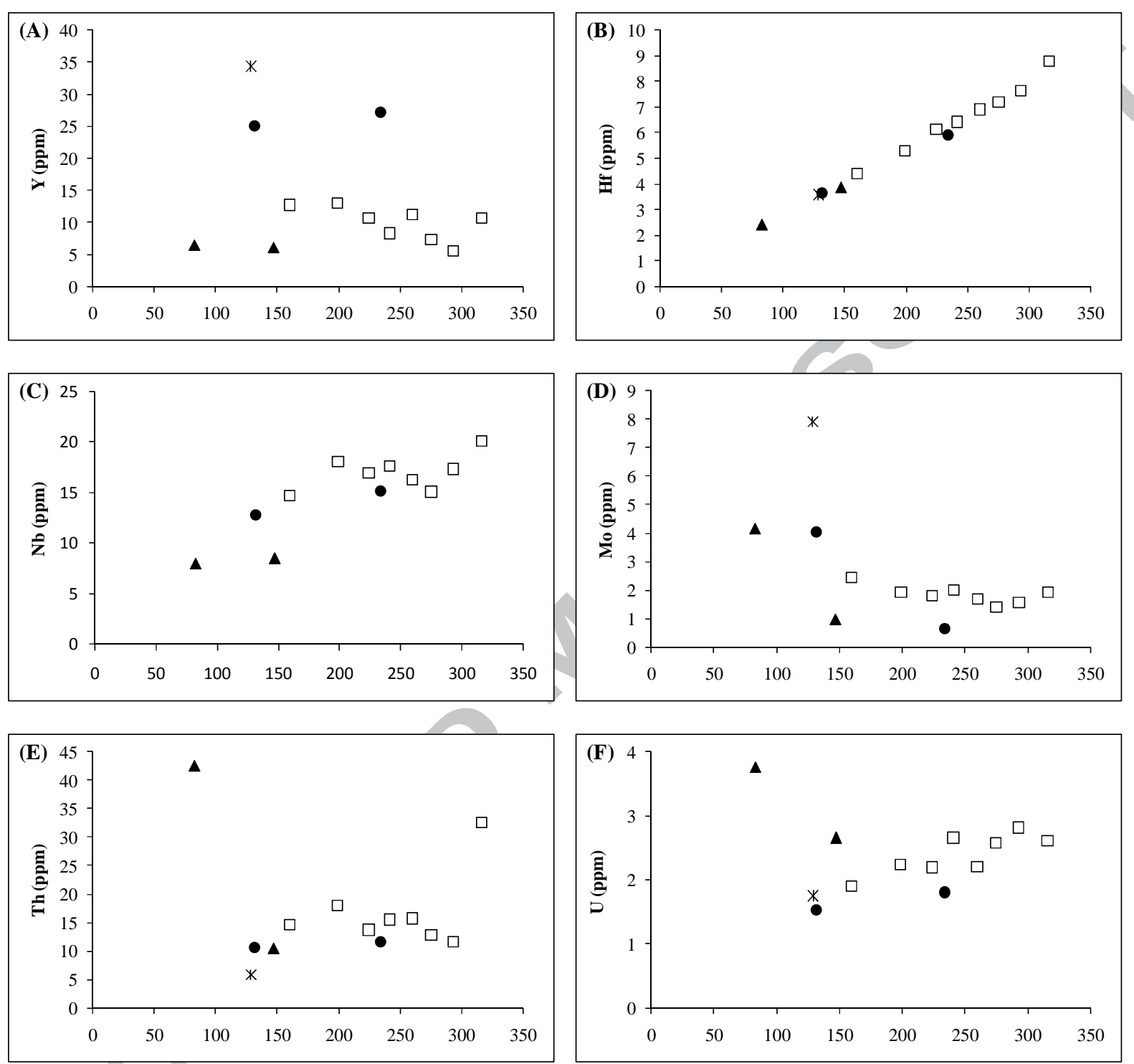

$\operatorname{Zr}(\mathbf{p p m})$

$\operatorname{Zr}(\mathbf{p p m})$

$\square$ Loose materials $\boldsymbol{\Delta}$ Iron duricrust

Parent rock

Figure 9 


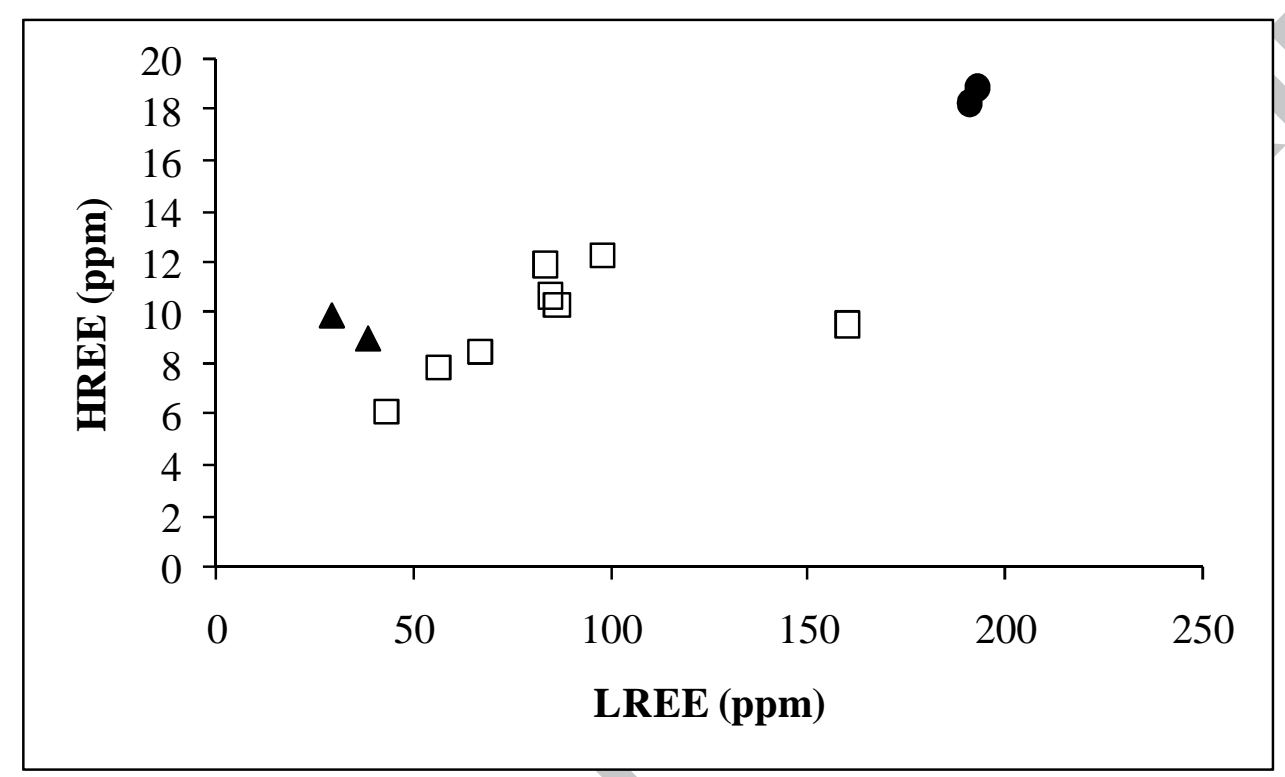

$\square$ Loose materials

$\Delta$ Iron duricrust

- Parent rock

Figure 10 

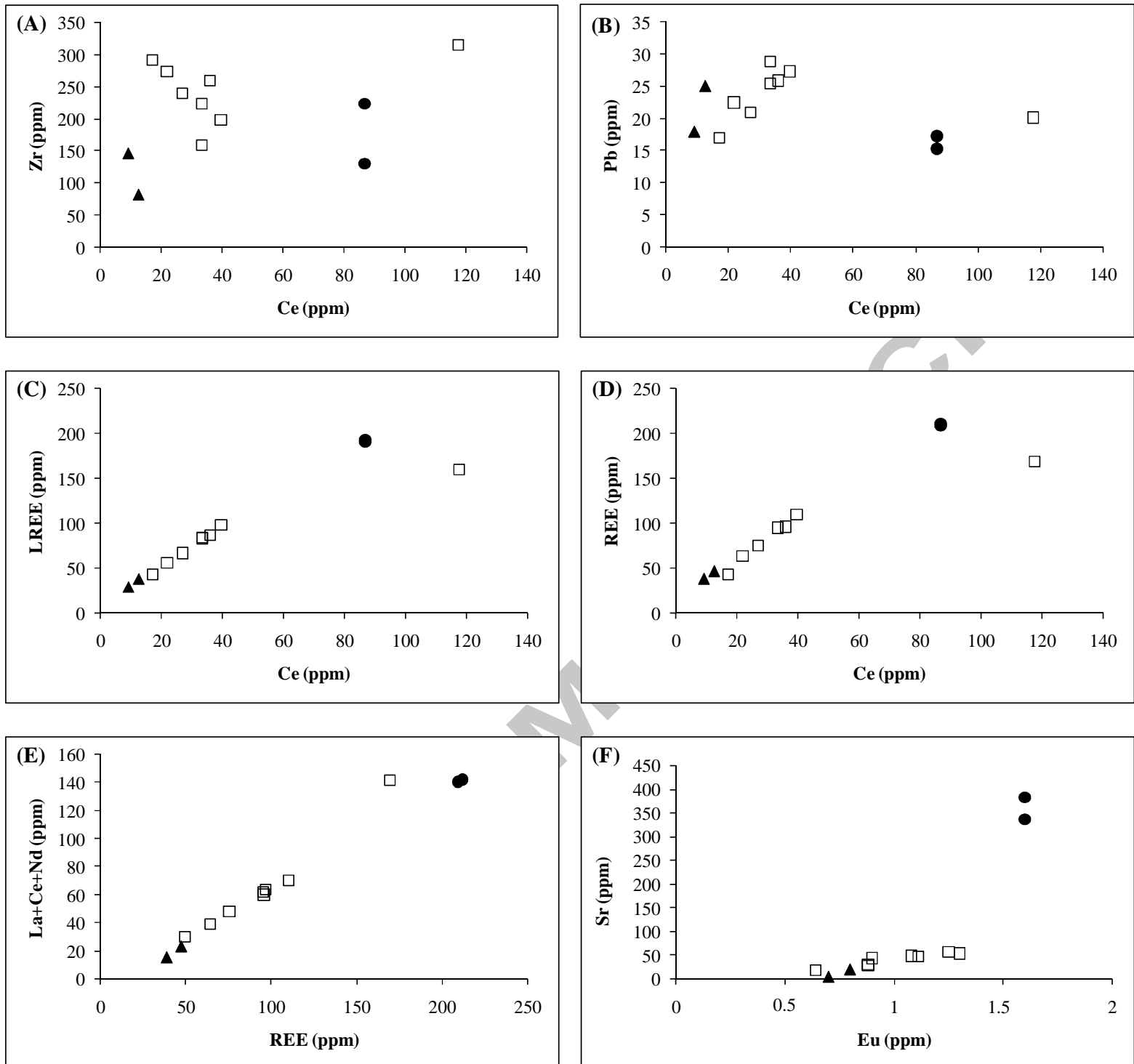

$\square$ Loose materials $\quad \Delta$ Iron duricrust

- Parent rock

Figure 11 

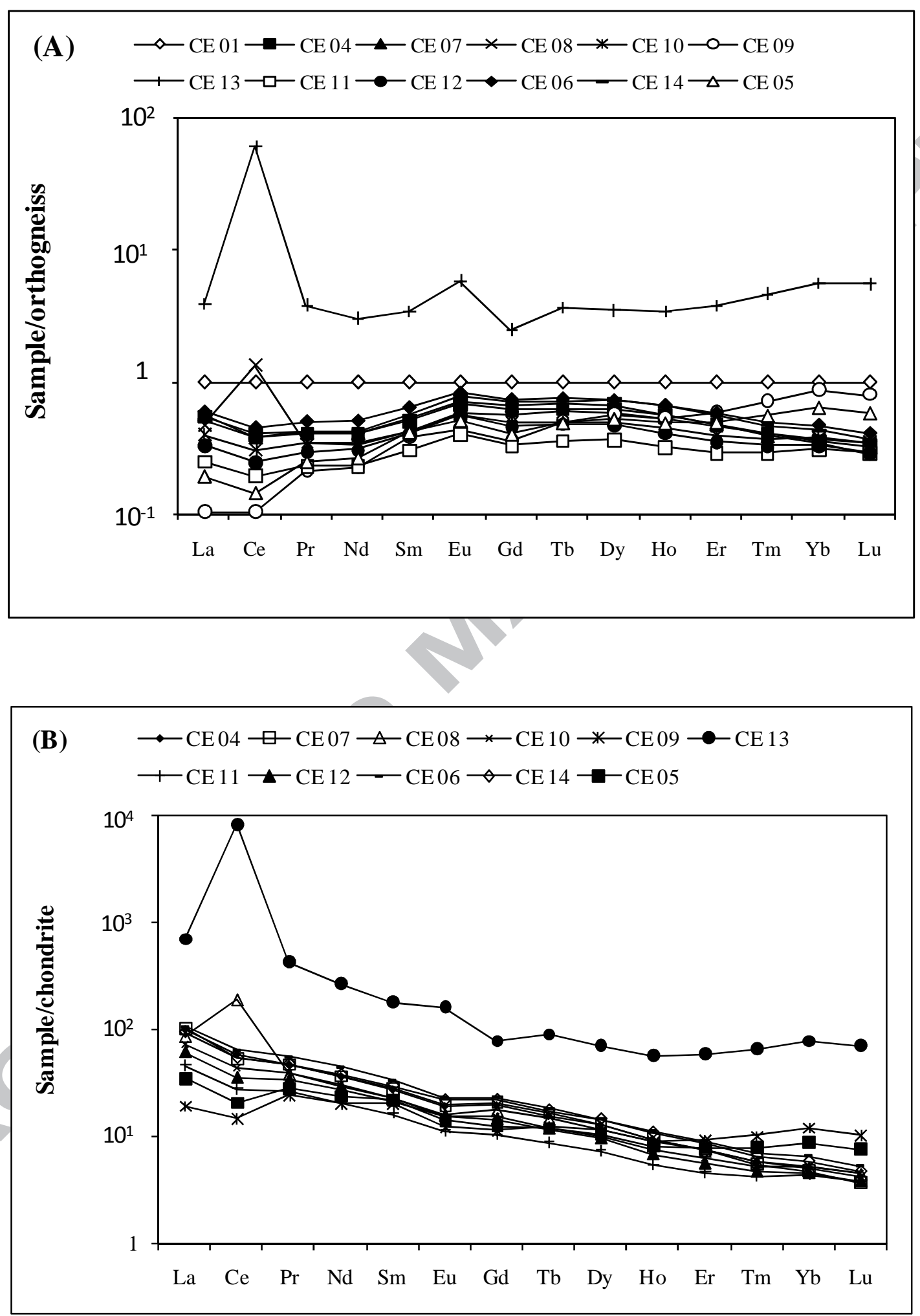

Figure 12 


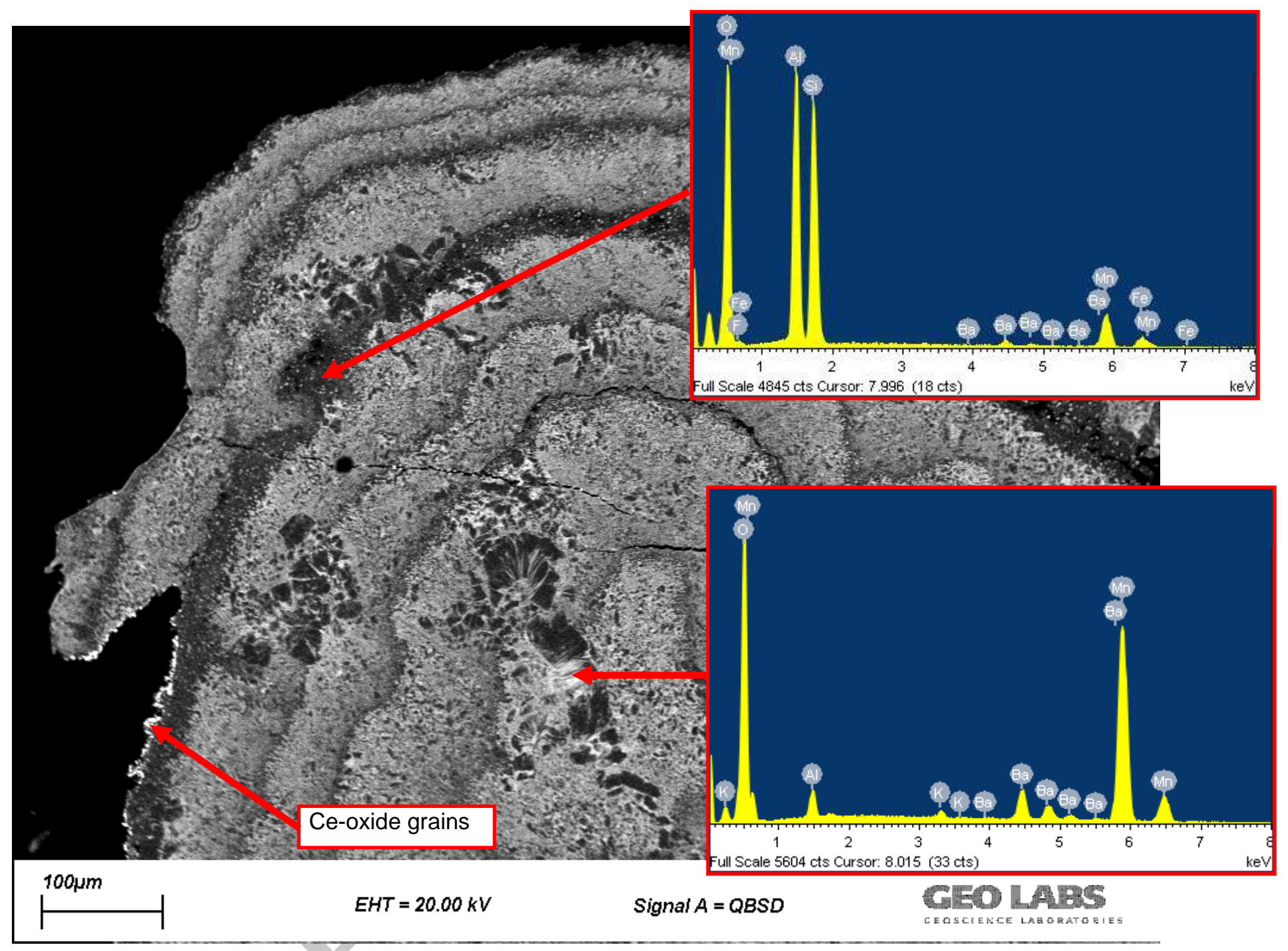

Figure 13 


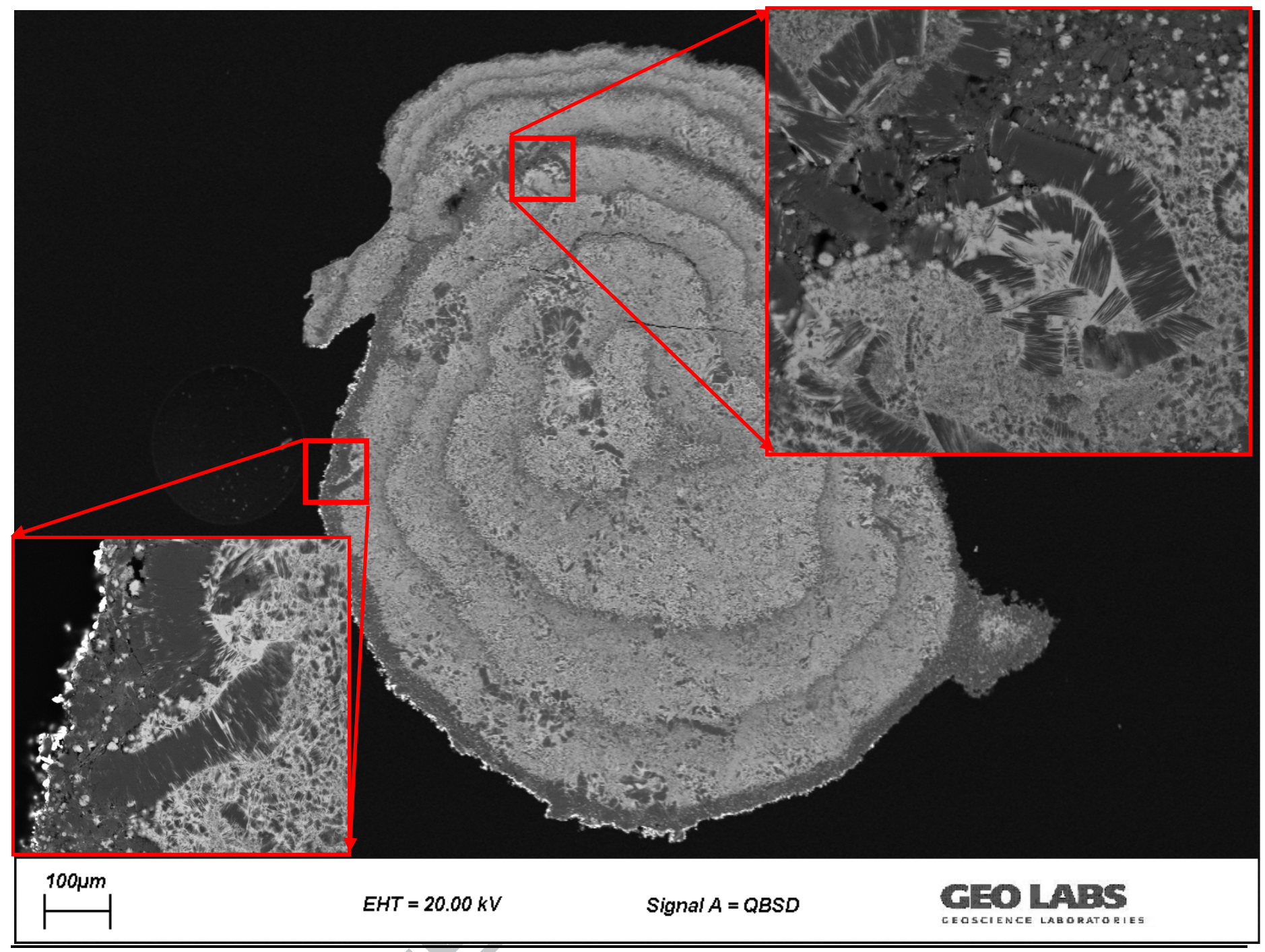

Figure 14 


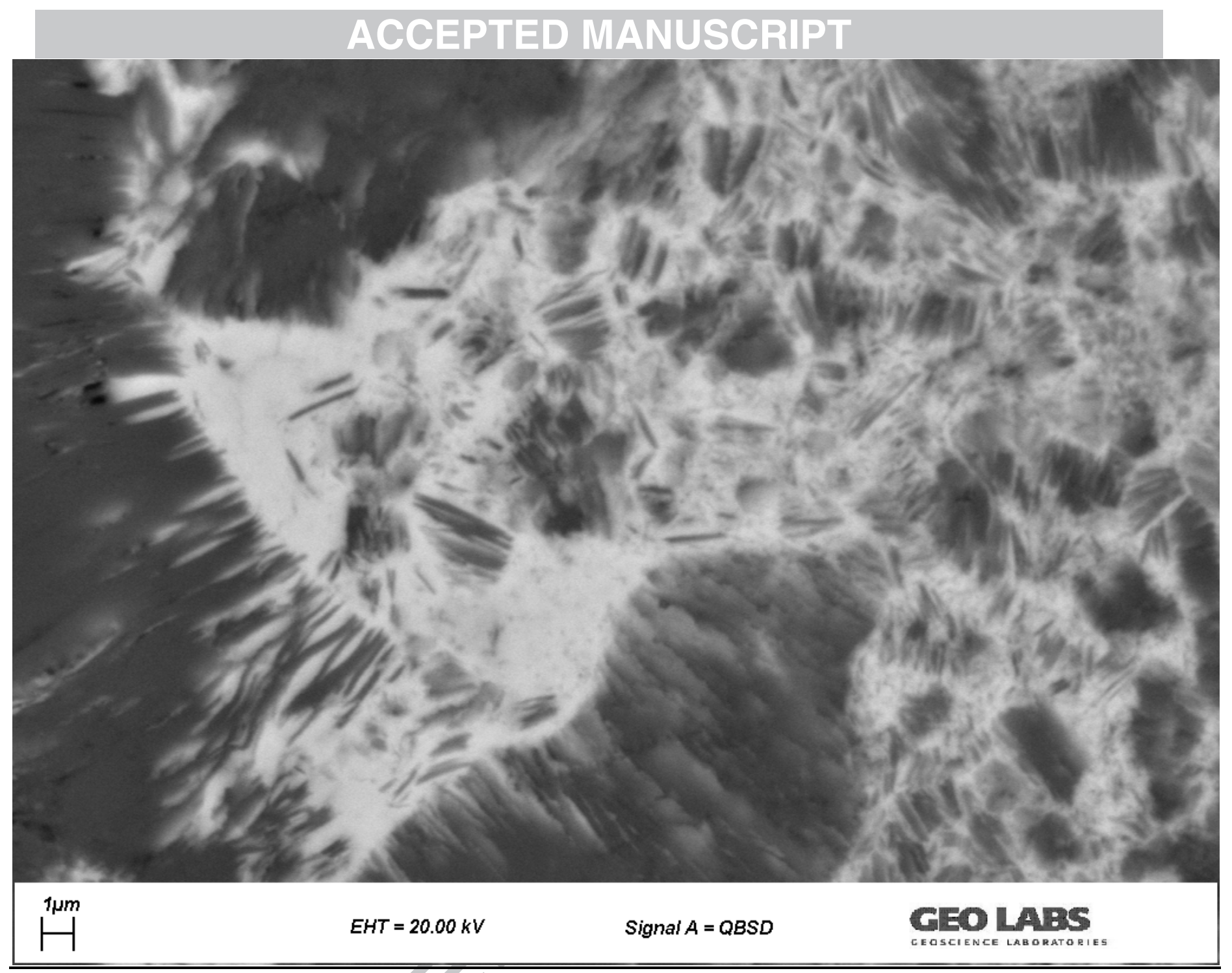

Figure 15 


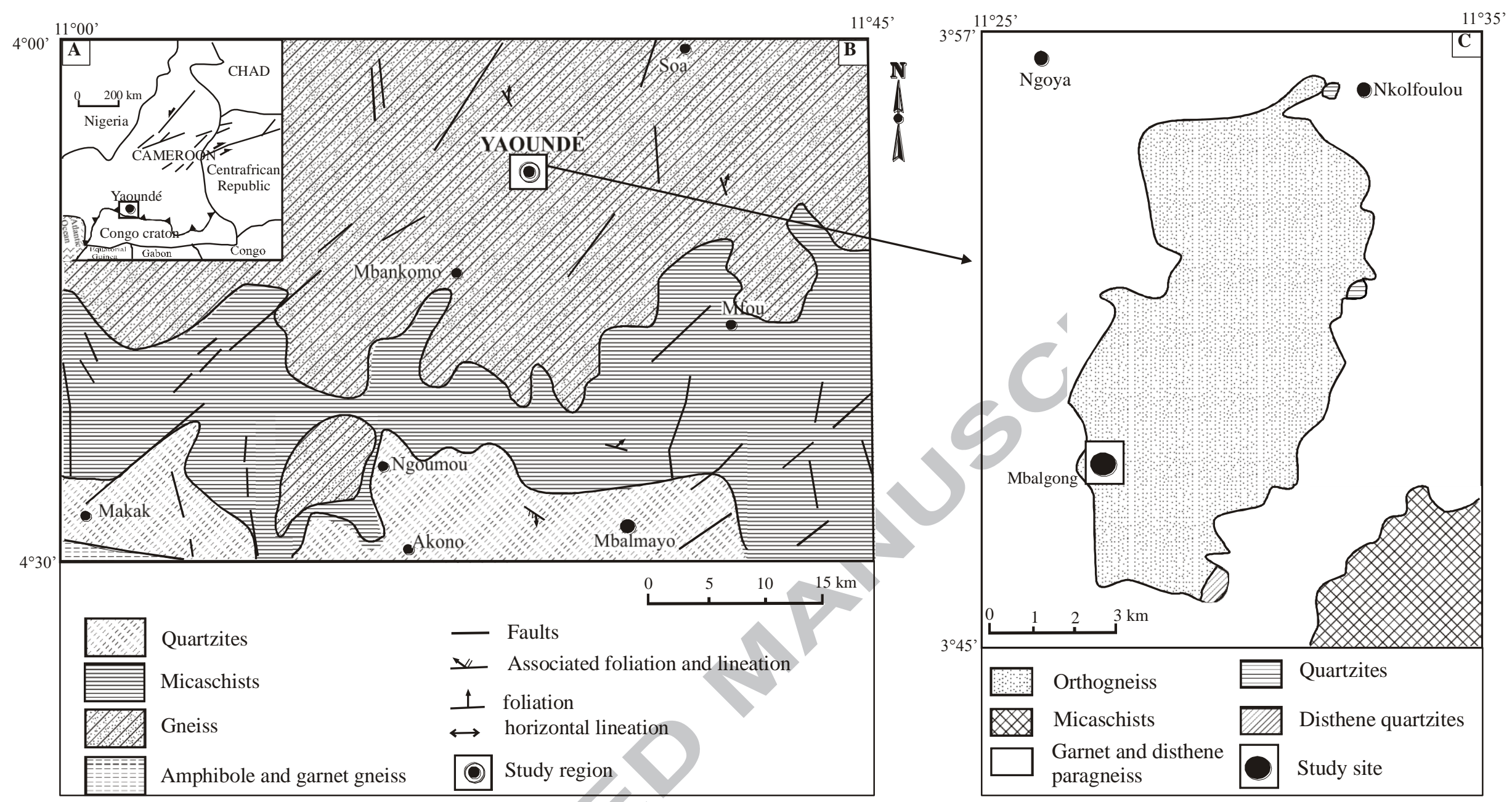

Fig. 1 


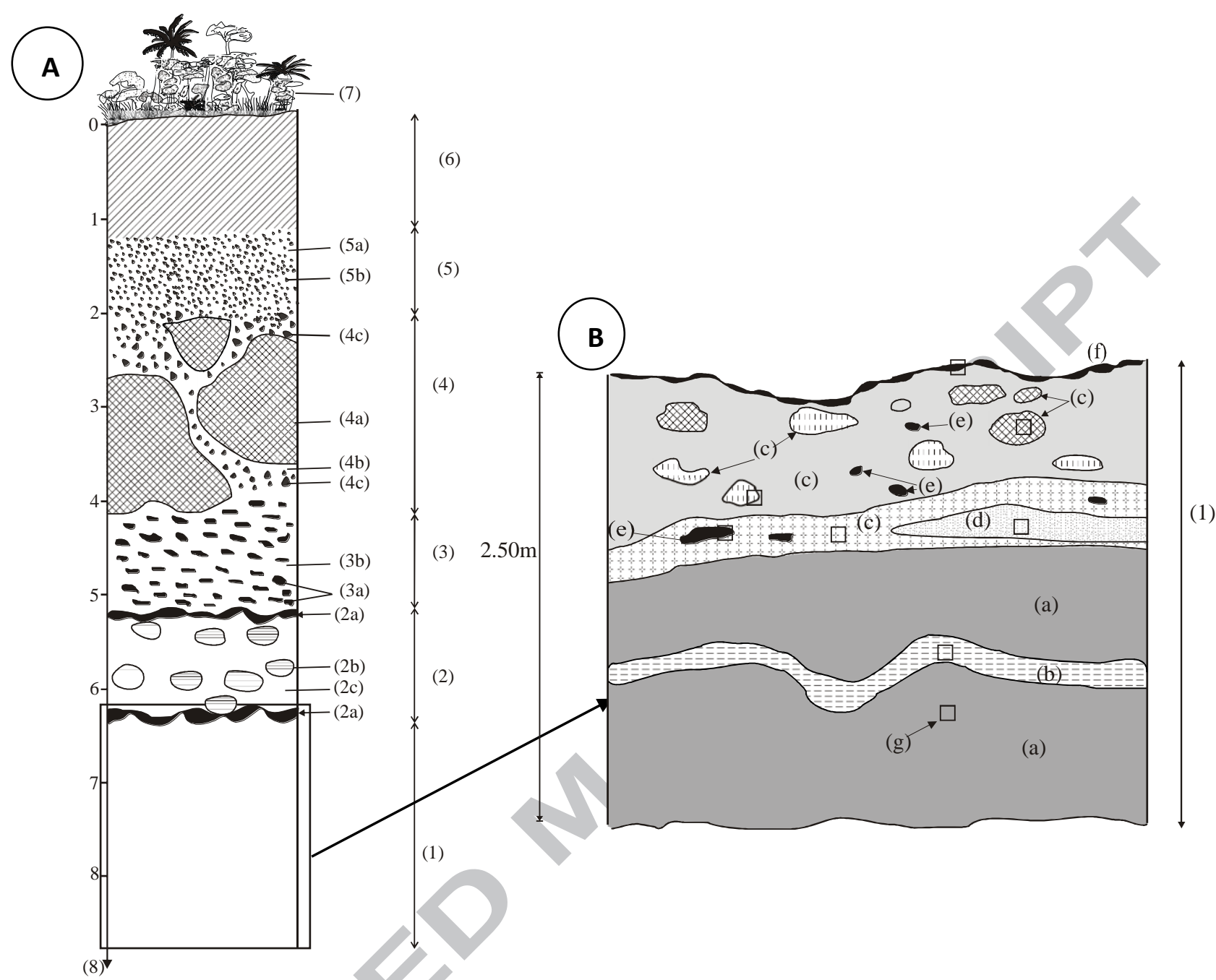

1. coarse saprolite (a. brown materials; b. white veins; c. yellowish brown plates; d. dark red iron duricrust; e. black plates; f. dusky red iron duricrust; g. sample location); 2. fine saprolite (2a: iron duricrust (plates); $2 \mathrm{~b}$ : plates with relic structure; 2c: patched materials); 3. lower nodular horizon (3a: flattened nodules with relic structure; 3b: dark red matrix); 4. iron duricrust horizon (4a: metric blocks of the nodular iron duricrust; 4b: red matrix; 4c. nodules); 5. upper nodular horizon (5a: red matrix; 5b: nodules); 6. clayey loose horizon; 7. vegetation; 8. Depth.

Figure 2 


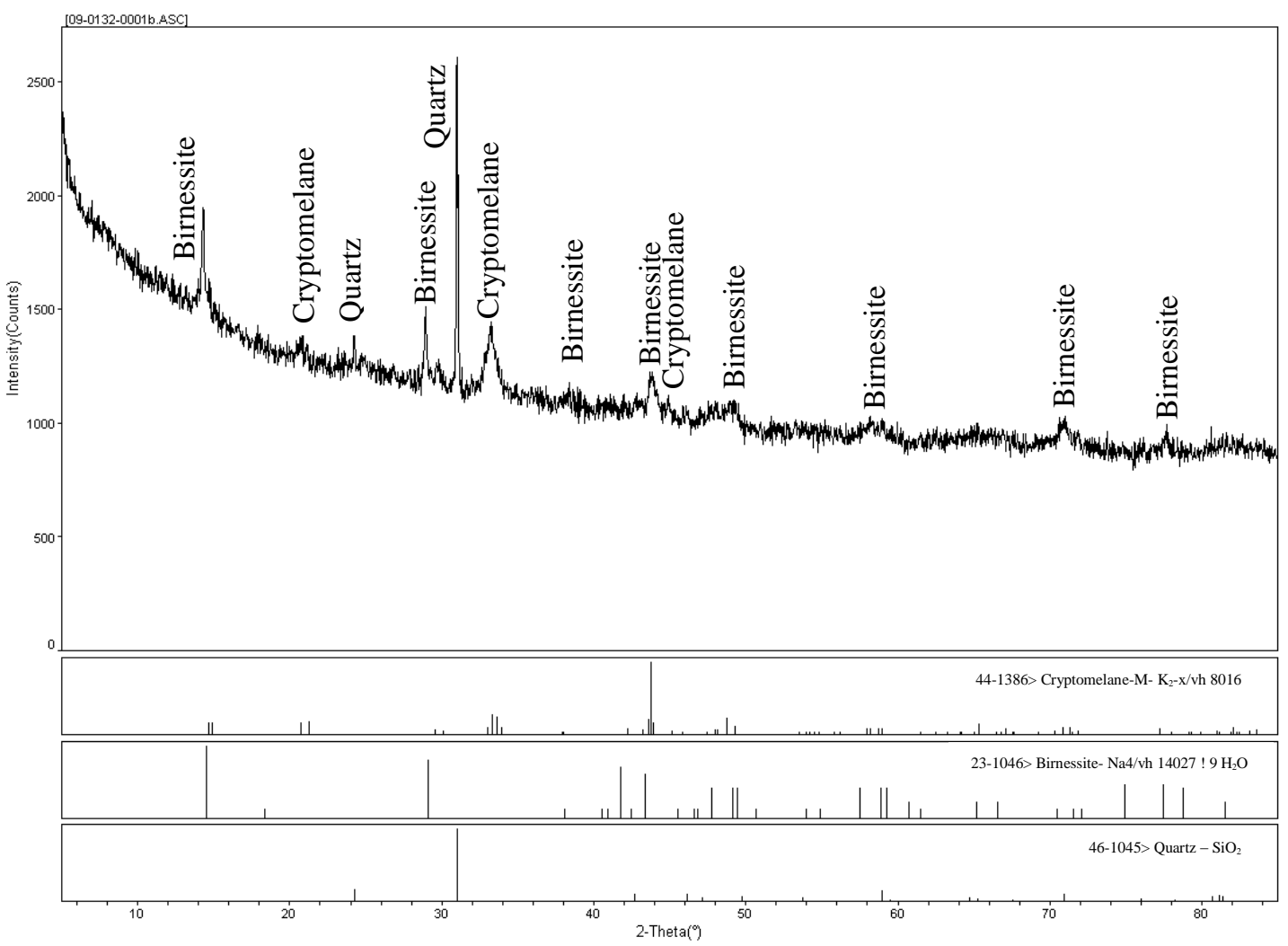

Figure 5 